Article

\title{
Profitability and Firm Value: Does Dividend Policy Matter for Indonesian Sustainable and Responsible Investment (SRI)-KEHATI Listed Firms?
}

\author{
Akhmadi Akhmadi ${ }^{1, *(D)}$ and Yeni Januarsi ${ }^{2,3}$ (D) \\ 1 Department of Management, Faculty of Economics and Business, University of Sultan Ageng Tirtayasa, \\ Jalan Raya Palka, Km. 3, Sindangsari, Kec. Pabuaran, Kabupaten Serang 42163, Indonesia \\ 2 Department of Accounting, Faculty of Economics and Business, University of Sultan Ageng Tirtayasa, \\ Jalan Raya Palka, Km. 3, Sindangsari, Kec. Pabuaran, Kabupaten Serang 42163, Indonesia; \\ yeni_januarsi@untirta.ac.id \\ 3 Graduate School of Economics, Kyushu University, Fukuoka 819-0395, Japan \\ * Correspondence: akhmadi@untirta.ac.id; Tel.: +62-859-4554-2292
}

Citation: Akhmadi, Akhmadi, and Yeni Januarsi. 2021. Profitability and Firm Value: Does Dividend Policy Matter for Indonesian Sustainable and Responsible Investment (SRI)-KEHATI Listed Firms? Economies 9: 163. https://doi.org/ 10.3390/economies 9040163

Received: 4 September 2021

Accepted: 21 October 2021

Published: 1 November 2021

Publisher's Note: MDPI stays neutral with regard to jurisdictional claims in published maps and institutional affiliations.

Copyright: (c) 2021 by the authors. Licensee MDPI, Basel, Switzerland. This article is an open access article distributed under the terms and conditions of the Creative Commons Attribution (CC BY) license (https:// creativecommons.org/licenses/by/ $4.0 /)$.

\begin{abstract}
This study investigates the potential factors explaining the inconsistent relationship between profitability and firm value. Specifically, it examines whether dividend policy contributes to the profitability-firm value relationship and determines the form of the moderating variables. We use a unique data set from the Indonesian capital market, with sustainable and responsible investment (SRI)-KEHATI-listed firms from 2010 to 2019. Adopting hierarchy moderating analysis, the results show a positive direct relationship between profitability and firm value. Moreover, the profitability-firm value relationship becomes stronger with a higher dividend policy ratio. We complement this with evidence that the dividend policy plays a role as a pure moderator in more sustainable and responsible firms. A sensitivity battery analysis and the endogeneity concern show consistent results as the baseline model, implying that the model is robust to different conditions. Additional tests revealed that the dividend policy is more prominent in low-leverage enterprises, low-intensity advertising firms, and during the financial service authority's post-dividend policy regulation phase. The implication of our study is that corporate policy and country regulation play a role as a potential competitive strategy to increase shareholder value for SRI-KEHATI-listed firms.
\end{abstract}

Keywords: profitability; firm value; dividend policy; hierarchy moderating regression; sustainability and responsibility investment (SRI)-KEHATI

\section{Introduction}

Firm value has been overwhelmingly studied for a few decades to better understand how numerous elements affect its creation. These studies include corporate social responsibility (Chune et al. 2018; D'Amato and Falivena 2020; Hu et al. 2018; Jadiyappa et al. 2021; Jo et al. 2016; Zhang and Shuang 2021) R\&D intensity (Kim et al. 2021), online information (Salvi et al. 2021), and corporate governance (Fauver et al. 2017; Ararat et al. 2017; Huang et al. 2020). As the primary indication of shareholder welfare, a firm value is considered a critical study topic. A higher firm value results in more shareholder wealth (Brigham and Gapenski 2006).

The irrelevance dividend theory (Miller and Modigliani 1961) suggests that a business's profitability affects its value. Since its introduction, studies have examined the role of profitability in firm value and investigated this relationship in various sample settings (Chen and Chen 2011; Liow 2010). The literature review in this study revealed conflicting findings of the relationship between profitability and firm value, as documented in (Handoko 2017; Hirdinis 2019; Harahap et al. 2020; Ardila et al. 2018; Bukit et al. 2018; Endri and Fathony 2020). We attempt to examine whether the mixed results for the profitability-firm value relationship can be explained by the dividend policy. Different from prior studies, 
we attempt to distinguish the form of the moderating role. We believe this is important because determining the form of the moderating variable can better enhance the accuracy of the analysis of the moderating role of a variable and provide comprehensive knowledge of the literature for moderating roles. In addition, we investigate this issue using firms listed as sustainable and responsible investments (SRIs), which is expected to enrich the literature by providing fresh evidence from a unique data set.

First, we examine the profitability-firm value relationship. Shareholder wealth and value improve when a firm produces greater profitability because it enhances the future firm performance. Moreover, firms with high profitability may gain greater investor trust, improving the company's value. Previous empirical research in specific industries (Salvi et al. 2021; Chen and Chen 2011; Liow 2010) found a positive association between profitability and firm value. Contrary to prior studies, using an Indonesian data setting, Handoko (2017) found a negative link between profitability and firm value, and the authors of Hirdinis (2019) documented no significant effect on this relationship. Due to inconsistent findings, it is interesting to re-examine the profitability-firm value relationship to provide deeper understanding of the profitability-firm value relationship, particularly when few studies have been conducted on sustainable and responsible investment (SRI) firms. This problem raises concerns about what this association would become for SRI companies. Therefore, this study fills this gap by focusing on SRI enterprises in the Indonesian capital market.

Second, we investigate dividend policy as a moderating variable in the relationship between profit and firm value. This study proposes that the dividend policy may strengthen the profitability-firm value relationship, as investors need to prioritize long-term returns such as dividends (Ghalandari 2013; Fairchild et al. 2014; Thanatawee 2014). They can increase their investment when they are positive about the current year's dividend performance because it increases future profitability. In this case, dividend policy may positively impact a company's value and improve its relationship with profitability (strengthen the moderating role). Furthermore, previous research did not consider the form of the moderating effect, whether it be as a pure or quasi-moderator, when examining the moderating role of a variable in the profitability-firm value relationship. This study uses hierarchy analysis (Sharma 2003) to assess whether the dividend policy acts as a pure or quasi-moderator of the relationship between profitability and company value.

Sustainable and responsible investment-keanekaragaman hayati Indonesia firms are known as SRI-KEHATI. This provides an appropriate framework for studying the profitability-firm value relationship. Having excellent financial performance and applying the principle of sustainable, responsible investment and environmental, social, and governance (ESG) principles, the SRI-KEHATI Index is a prominent Indonesia Stock Exchange (IDX) index. It has a market valuation of roughly IDR 1 billion and has been used by 11 fund management companies with total asset management of approximately IDR 2.5 trillion. However, only a few studies have examined the profitability-firm value relationship using SRI-KEHATI firms. Therefore, this study attempts to complement the sustainability and firm value literature by witnessing that sustainable firms contribute to firm value creation. Focusing on SRI-KEHATI firms to examine the association between profitability and firm value may enhance our understanding of shareholder value creation in a more sustainable firm. Therefore, it is interesting to examine the relationship between profitability and firm value in sustainable and responsible firms in emerging markets, such as the Indonesian capital market.

This study contributes to the body of knowledge in several important ways. First, the current study presents evidence concerning the form of the moderating variable to supplement the previous literature. As the first study which distinguishes the form of the moderating effect using SRI-KEHATI-listed firms, we provide the additional insight that the dividend policy has a pure moderating function in the profitability-firm value relationship which was overlooked by most previous studies. This means that a combination of dividend policy and profitability will strengthen the value creation of a company. However, when 
the dividend policy becomes the single driving variable, it may not give the greatest impact to the firm value, as we find that dividend policy plays a role as a pure moderator for SRI-KEHATI-listed firms. Second, the current study may enhance our understanding regarding the form of moderating variables because we provide evidence that a variable may have an opportunity to become a pure moderating variable or quasi-moderating variable. It is essential to distinguish both forms to gain deeper and more precise analysis when examining the role of the moderating variable. Third, the Indonesian capital market regulators and Financial Services Authority may use the current study's findings as a reference to design regulation regarding dividend policy or the minimum amount of cash on hand which can be paid as dividends to their stockholders. Our findings also provide the opportunity to be extended to other scholars interested in similar research topics and provide broader evidence by using a larger sample including other countries. Fourth, there is a scarcity of academic interest in SRI-KEHATI firms to investigate the profitability, dividend policy, and company value relationship in emerging markets. This is plausible because SRI-KEHATI is the only green index in ASEAN and the second in Asia, with little expert recognition from developed market countries. Therefore, this study helps close this research gap. Fifth, we contribute to the Indonesian capital market regulators and Financial Services Authority by providing fresh evidence that dividend policy regulation may become crucial for listed companies. Capital market regulation concerning dividend policy should be taken with more caution and assessed more carefully, as it may affect a shareholder's value creation.

The rest of the paper is organized as follows. Section 2 reviews the literature and hypothesis development, while research design will be presented in Section 3. Section 4 provides the results, and Section 5 discusses the findings. Section 6 provides the conclusion.

\section{Literature Review and Hypotheses Development}

\subsection{SRI-KEHATI Index}

The Sustainable and Responsible Investment (SRI)-KEHATI Index is the first green index in ASEAN and the second in Asia. It was officially launched on 8 June 2009 by the KEHATI Foundation in partnership with the Indonesia Stock Exchange (IDX). The SRI-KEHATI Index is now the only reference for investing principles that focuses on ESG issues in the Indonesian capital market. Furthermore, it focuses on company selection rules that apply the principle of sustainable responsible investment (SRI) and environmental, social, and governance (ESG) legislation. The SRI-KEHATI Index constituents are chosen based on the company's core features, financial elements, and factors of the business impact on the environment.

The index begins with companies listed on the IDX. A company with a negative list is removed from the list in the first round, leaving only firms with positive environmental and sustainability policies. In addition, firms involved in pesticides, nuclear energy, armament and weaponry, tobacco, alcohol, pornography, gambling, genetically modified organisms, and coal mining are on the negative list and should be excluded. Small companies are eliminated in the second stage by screening the firm's financial qualities. Firms with a market capitalization of less than IDR 1 trillion, total assets less than IDR 1 trillion, low share availability (free float ratio less than $10 \%$ ), and negative price/earnings (PE) ratio are omitted from the list. Finally, in the third stage, the remaining companies are appraised by a top ESG research firm using international ESG criteria tailored for Indonesian regulations. These include the environment, societal involvement, company governance, supplier and customer behavior, labor practices, and human rights. Therefore, 25 enterprises were chosen to form the index's competitive list.

The authors of Williams (2010) suggest that the SRI-KEHATI became an essential index in Indonesia's capital market and Asia for various reasons. First, SRI is important in Asia's emerging markets and is not limited to rich, industrialized economies. Its critical function is shown in its increasingly popular index employed by 11 fund management businesses with about IDR 2.5 trillion in assets under management. Second, SRI is a successful investment 
option because it outperforms traditional indices, such as the LQ 45. Third, two new SRI funds, Mega Capital and Bahaya Fund Management, have developed easy access to sustainable investment products by utilizing the SRI-KEHATI Index. Subsequently, they provide institutional and retail investors easy access to sustainable investment products. Fourth, the SRI-KEHATI Index assists companies in improving their sustainability management. It provides fund managers and shareholders with the opportunity to understand better ESG investment methods and their online information sources and training programs. Finally, it provides an authentic example for other stock exchanges, demonstrating the value of developing SRI indices across the area.

Since its launch, the SRI-KEHATI Index has performed better than several primary indexes, such as the Composite Stock Price Index (CSPI), Index Harga Saham Gabungan (IHSG), and LQ45. In 2021, the index had a market capitalization of around IDR 1 billion. It has been used by 11 fund management companies with approximately IDR 2.5 trillion in asset management. The SRI-KEHATI Index was established to enable investors and potential investors to possess more investment choices in a firm concerned with its financial and environmental performance and sustainability.

\subsection{The Related Literature and Hypothesis Development}

\subsubsection{Profitability and Firm Value}

Firm value studies have been widely explored in the other literature, such as finance, accounting, taxation, and management. Extensive studies show that the financial factor is essential in creating shareholder value. The authors of Jadiyappa et al. (2021) examined whether financing diversification affects firm value in India. The study used debt diversification to proxy financial diversification and found that debt diversification negatively impacts firm value among group-affiliated firms. Another factor that affects firm value is liquidity. Using data from the non-financial industry from Bursa Malaysia from 2000 to 2015, the authors of Chia et al. (2020) examined the relationship between liquidity and firm value. Additionally, it examined the moderating role of political connections in this relationship. The results showed a nonlinear ( $\mathrm{U}$-shaped curve) relationship between liquidity and firm value, suggesting that liquidity and firm value are negatively related. Moreover, the relationship turns positive when liquidity increases above the threshold level. The authors of Kim et al. (2021) examined the financial characteristics of firm value. They examined the effect of R\&D intensity on the value of financially constrained firms with dividend policy as a moderating variable. Additionally, the study used 11.946 as the firm's year observation from the United States capital market, and the sample period covered 1980-2017. The results showed that $R \& D$ significantly affects the value of financially constrained firms with dividend payout policies. The effect is more significant than that on the importance of firms without dividend payout policies.

The selected industry also explains firm value creation in a unique industry setting. For instance, the authors of Ghalandari (2013) examined the effect of the food recall and CSR on firm value in the food industry. The results showed that corporate social responsibility (CSR) mitigates the negative impact of food recalls on shareholders' wealth. A similar finding was also documented in Abdi et al. (2020) in the air transport Industry. Furthermore, the authors of Ong and Chen (2014) focused on InformationWeek's top 100 IT leaders, ranking firms and examining the impact of IT capabilities on a firm's performance and value. The results showed that IT capabilities significantly contribute to firm value more than firm performance. These studies show that every industry explains shareholder value creation in a unique set of the capital market. While previous studies focused on a unique setting with different factors to examine the firm value, this study explores profitability as an essential financial factor in firm value creation.

The authors of Liow (2010) examined the effect of profitability and two other factors on company value in the real estate market. It is implied that, in following the literature on value-based planning, corporate management builds shareholder value by ensuring that the warranted market value (MV) of the equity capital invested in the firm by the shareholders 
exceeds the book value (BV). The results showed that successful real estate companies are generally profitable. This implies that profitability positively impacts shareholder value creation. Even though the authors of Chen and Chen (2011) and Salvi et al. (2021) examined different industries, their findings supported those in Liow (2010).

Another study examined the relationship between profitability and firm valuation using data from the Indonesian capital market, and the authors of Chune et al. (2018); Cleary (1999); Harahap et al. (2020); Ardila et al. (2018); Bukit et al. (2018); Sutopo and Hananto (2019) proved there was positive evidence of this relationship. For instance, in Ardila et al. (2018), whether state ownership enterprises (SOEs) outperform non-SOEs was investigated using a sample of 297 observations from 2012 to 2016. Their study found a positive and significant relationship between profitability and firm value. They also showed that the influence of profitability on the firm value for SOEs is not different from the effect of profitability on the firm value for non-SOEs. They suggested that the indifferent outcome between SOEs and non-SOEs is because SOE companies use cost or expense inefficiently, and there may be some manipulating behavior in SOE companies. The authors of Bukit et al. (2018) investigated whether environmental performance, business profitability, and asset utilization may increase firm value in intense and less-intensive debt monitoring. They found that in intensive monitoring, managers tend to have high firm value when a company has high environmental performance or high profitability and high asset utilization. This implies that the monitoring system should be strengthened for companies with the characteristics mentioned earlier. However, the findings in Harahap et al. (2020) contradict those findings. Using a sample of four manufacturing cable subsector companies listed on the Indonesia Stock Exchange, their findings revealed that profitability negatively impacts firm value. This is because firms employ high debt to support their operations, creating a negative perception among investors. This negative association between profitability and firm value is also in line with the findings in Chia et al. (2020).

Despite the inconclusive findings from the above-mentioned empirical studies, we offer several explanations to justify the positive relationship between profitability and business value. Increasing profit may enhance a firm's dividend ratio, as stated by signaling theory. Subsequently, investors would expect larger returns and higher stock prices, resulting in more corporation value. Another explanation is that profitability reflects a firm's ability to generate operational efficiency (Chen and Waters 2017). Investors anticipate that high firm efficiency increases shareholder return, supporting a larger stock investment portfolio. When the stock investment portfolio grows larger, the firm's value may increase. Finally, we argue that profitability may affect company value, since it increases investor and shareholder trust. Higher profitability gives investors and shareholders a positive profile of the firm's accomplishments and increases their loyalty. Therefore, they retain their money invested in the firm's stock, add or buy more shares, and increase stock prices and its values. Moreover, for SRI-KEHATI firms, gaining shareholder and investor trust seems to be easy. This is because the firms win shareholder and investor trust through their high performance and environmental, sustainability, and social concerns. This supported by Chune et al. (2018), D'Amato and Falivena (2020), and Hu et al. (2018) which suggest that firms with high CSR activities could enhance a firm's value. Based on these arguments, we posit the following hypothesis.

Hypothesis 1 (H1). Profitability has a positive association with a firm's value in SRI-KEHATIlisted firms.

\subsubsection{Profitability, Dividend Policy, and Firm Value}

Our literature review documented only few studies revealing a negative association between dividend policy and firm value ${ }^{1}$ and most scholars documented a positive relationship between dividend policy and firm value (Olweny 2012; Bhattacharya 1979; Theodoulou et al. 2010; Skinner and Soltes 2011). The information in the dividend announcement influences the future value of the company. This is because when a firm 
announces the dividend, it directly signals the capital market regarding its future performance (Bhattacharya 1979). A higher dividend payout becomes an indicator for a higher expected return. A high dividend payout strategy shows a firm's ability to increase financial shareholder claims and can enhance their wealth. The firm's value creation improves as it sets a high dividend ratio. Ultimately, it increases the market value of shares and the company's value (Olweny 2012; Theodoulou et al. 2010; Skinner and Soltes 2011). Additionally, a high dividend policy strategy strengthens firm reputation and is an excellent way of fairly distributing wealth among shareholders (He and Chen 2007; Benlemlih 2019), increasing firm value. For instance, it was shown in Sawicki (2009) that a high dividend payout ratio improves decent corporate governance in emerging countries. Similarly, several studies show that paying an increased dividend may lower the agency cost and mitigate information asymmetry. This is because it reduces the discretionary funds, which may harm value-destroying projects (Faccio et al. 2001; Gomes 2000). Therefore, firms paying high dividends are perceived to be less risky and contribute to shareholder value creation.

This study examines the moderating role of dividend policy. The authors of Sharma (2003) suggested two forms of a moderating role as a pure or quasi-moderator. Dividend policy may become a pure moderator, meaning that it interacts with profitability but has no correlation with the firm value (i.e., does not play a role as an independent variable). We posit that this is because investors in environmental, social, and sustainability enterprises hardly consider dividend policy as the major driver of corporate value maximization. They are more likely to address ecological, social, and sustainability challenges to increase the firm's value. Previous studies support this line of reasoning that CSR increases company value (Chune et al. 2018; D'Amato and Falivena 2020; Hu et al. 2018; Jadiyappa et al. 2021; Jo et al. 2016). In contrast, dividend policy can act as a quasi-moderator by playing a role as an independent variable and also as a moderating variable by meeting the interaction requirement between profitability and dividend policy. Dividend policy may link with profitability because dividend policy can forecast future profitability; hence, both variables may interact (Fairchild et al. 2014). Dividend policy may also become an independent variable that connects with firm value. Previous research suggested that dividend policies could reward investors or enhance value creation (Kim et al. 2021).

In short, whether dividend policy supports a pure or quasi-moderator form, this study proposes that the relationship between profitability and firm value becomes stronger when a firm sets a high dividend policy ratio. When a dividend policy is announced to the public, the firm achieves a higher expected return and gains an excellent reputation from the capital market. In addition, it reduces information asymmetry and creates more profitability for the company, which improves a firm's value. Therefore, the following hypothesis is proposed.

Hypothesis 2 (H2). The relationship between profitability and firm value is moderated by dividend policy in SRI-KEHATI-listed firms. Therefore, the positive relationship between profitability and firm value is stronger because of the dividend policy in SRI-KEHATI-listed firms.

\section{Research Design}

\subsection{Data and Sample Selection}

The variables in this study were measured using data from the BVD Osiris database, which comprised the SRI-KEHATI listed firms between 2010 and 2019. Data were collected from 2010 because much data were unavailable in the database before this year, reducing the number of samples. Additionally, the SRI-KEHATI Index was first launched in the middle of 2009. Therefore, it was reasonable to wait until 2010, when the capital market broadly understood the index. SRI-KEHATI firms belonging to the financial and banking industry were excluded because they have specific regulations and characteristics that affect the financial number in the financial statement. Following the method in Mousa et al. (2021), we excluded firms with 3 years in a role that had missing data, resulting in 170 firm year observations from 17 SRI-KEHATI-listed firms. 


\subsection{Measurement of Variables and Empirical Specification}

\subsubsection{Dependent Variable}

To measure the firm value, we used the market stock price. Extensive studies use Tobin $Q$ as a firm value measurement, though it has some drawbacks. Due to its drawbacks, we used the share price as the primary firm value measurement (Mousa et al. 2021). The share price captures various available capital market information and reflects updated firm value measurements. Accordingly, the share price can account for firm value proxies. The current study defines the market share price as the average of the shares' high and low market prices. Alternatively, for the robustness test, this study uses the firm's stock price $\log$ value at the end of the year in the sensitivity test to broadly explain the firm value proxy. This follows a market-based standpoint which suggests that the firm value could be determined using market share price.

\subsubsection{Main Variable}

The first primary independent variable in this study is firm profitability. We used return on assets (ROA) for the baseline model due to the extensive use of profitability measurement in the financial literature (Bedford et al. 2021; Hirshleifer et al. 2018; Otero-González et al. 2021). The robustness test involved the use of three other profitability measurements (Liu et al. 2019). The authors of Liu et al. (2019) suggested that profitability measurement could be noisy and subject to manipulation. Therefore, the study proposed three proxies, including gross, operating, and net profitability. It is posited in Liu et al. (2019) that gross profitability is less subject to contamination than operating and net profitability. Additionally, the three profitability measures are not directly affected by market valuation. Therefore, this study employed three alternative measurements of profitability. First, gross profitability, which is defined as the gross profit scale by total assets ((REVT - COGS)/AT). As gross profitability is recorded at the top of the income statement, this measurement is the cleanest and least subject to manipulation by management. Second, we used operating profitability, which is defined as the operating profit scale over the total assets, or (OIBDP)/AT. In this case, operating profitability was based on the firm's operating income before depreciation. Third, this study used net profitability, which is the net income scale over the total assets ((NI)/AT). Net profitability is at the bottom of the income statement and therefore the noisiest measure.

The second primary variable is the dividend policy. For our baseline analysis, we used a dummy variable of one for a firm which pays dividends and 0 otherwise, following the method in Chen and Steiner (1999). The robustness test measured the dividend policy using the dividend payout ratio (DPR), defined as earnings per share deflated by the dividends per share (Chen and Steiner 1999; Miller and Rock 1985).

\subsubsection{Control Variable}

The empirical finance literature has explored the determinants of the firm value. Therefore, this study controls for those standard factors to isolate the independent effect of profitability and dividend policy. First, the study control for a possible impact of financial distress was adopted from (Zaretzky and Zumwalt 2007). This study included financial distress as a control variable because a distressed firm experiences low firm value and low return. Second, we included the capital output because the capital expenditure may affect the firm value, as it finds a positive association with the stock price, thus influencing the firm value. In addition, capital expenditure provides an economic benefit, affecting the firm value (Han and Manry 2004). Capital outputs are defined as natural log values from capital expenditure at the end of the year (Chia et al. 2020; Han and Manry 2004; Ahmed and Falk 2006; Fauver et al. 2017). Third, this study controlled for the possible effect of a firm's operating capability. This is because a firm with sufficient free cash flow can overcome the financial constraint problem, indicating its ability. The freer the cash flow, the more management alleviates the financial constraints and positively impacts value creation. We captured the firm's ability using cash flow abundance, which is defined as the net 
operating cash flow normalized by the total operating revenue (Hu et al. 2018; Cleary 1999). Fourth, this study controlled the advertising intensity, which was measured by a firm's selling, general, and administration expense (SGA). The previous literature shows that as firms promote their market images, the stakeholder or investor reaction may influence this advertising, affecting the firm value (Hu et al. 2018; McWilliams and Siegel 2000; Miller and Rock 1985). Lastly, this study controlled for the industry- and year-fixed effects (industry and year dummies) to explain the macro variation and time-invariant industry factors (Miller and Rock 1985).

\subsection{Model Specification}

This study applied hierarchy moderating analysis to test the first and second hypotheses using the following equations:

$$
\begin{gathered}
F V_{t}=\beta_{0}+\beta_{1} R O A_{i, t}+\beta_{2} C V_{i, t}+\varepsilon_{i, t} \\
F V_{t}=\beta_{0}+\beta_{1} R O A_{i, t}+\beta_{2} D I V_{i, t}+\beta_{3} C V_{t i,}+\varepsilon_{i, t} \\
F V_{t}=\beta_{0}+\beta_{1} R O A_{i, t}+\beta_{2} D I V_{i, t}+\beta_{3} R O A_{i, t} * D I V_{i, t}+\beta_{4} C V_{i, t}+\varepsilon_{i, t}
\end{gathered}
$$

We define all the variables in Appendix A. To test the direct effect of profitability on firm value, for the first hypothesis, we expect a positive sign for $\beta_{1}$ in Equations (1)-(3). The hierarchy moderating regression in Equations (1)-(3) was adopted to examine the moderating effect of the dividend policy on the relationship between profitability and firm value. We also used these equations to determine the form of the moderating variables. The pooled ordinary least square standard error clustered by firm and year was used in every model according to (Fauver et al. 2017). This aimed to address heteroscedasticity and time series dependency in the panel data set.

The prior moderating literature documented two forms of moderating variables: pure and quasi-moderators (Otero-González et al. 2021). A pure moderator is a variable that interacts with an independent variable but has no correlation with a dependent variable (Sharma 2003; Cohen et al. 1975; Sharma and Patterson 1999). A quasi-moderator not only interacts with but is also an independent variable. Hierarchy moderating regression (Sharma 2003). was performed to identify whether the dividend policy had a role as a pure or quasi-moderator using Equations (1)-(3).

Following this method, first, it was essential to determine whether there was a significant interaction between the independent variables and the moderator. To determine this requirement, hierarchical moderated regression focused on whether Equations (2) and (3) were different $\left(\beta_{3} \neq 0\right)$ or whether $\beta_{3}$ was significant. Second, in case $\beta_{3}$ was significant, the relationship of the moderator and the dependent variables was determined by assessing whether Equations (1) and (2) were different $\left(\beta_{2} \neq 0\right)$. By adopting criteria from Sharma (2003) to determine the form of the moderating variable, dividend policy played a role as a pure moderator variable when $\beta_{1}$ and $\beta_{3}$ were significant and while $\beta_{2}$ was insignificant. In contrast, it served as a quasi-moderator variable when $\beta_{1}, \beta_{2}$, and $\beta_{3}$ were all significant. Additionally, dividend policy did not play a moderator role when the interaction between the moderator and independent variable was insignificant.

\section{Empirical Results}

\subsection{Descriptive Statistics}

This study investigated publicly listed SRI-KEHATI firms in the Indonesian capital market and collected financial data from the OSIRIS database from 2010 to 2019. Additionally, all variables were winsorized at $1 \%$ and $99 \%$ levels to mitigate outliers. This resulted in 170 firm year observations represented by 17 firms listed on the SRI-KEHATI Index. Table 1 summarizes the descriptive statistics for the full sample across the SRI-KEHATI firms. The primary firm value proxy shows that the average market price (FV) had a mean value of 0.461 with a standard deviation of 0.581 , indicating low diversity in firm values. The $\log$ of the firm stock price (FV_2) showed -1.803 for the mean and 1.538 as the standard 
deviation. The large standard deviation of the log of firm stock price (FV_2) shows that the SRI-KEHATI firms had high diversity in firm stock prices. This is probably because SRI-KEHATI firms are popular indices in IDX, causing their stock price to change promptly. Concerning profitability measurement, the ROA documented mean was 8.498, and the standard deviation was 9.577, indicating that the SRI-KEHATI firms had a similar ability to generate profit. This profile meets the requirement from the SRI-KEHATI committee that every firm indexed must have a good financial ratio background. Moreover, the other three profitability measurements, including gross profit (Gross), operating profit (OP), and net profits (NET), showed low diversity among the SRI-KEHATI firms. As a dividend policy proxy alternative, the DPR had a mean of 29.57 with a standard deviation of 29.05, implying that the SRI-KEHATI firm had similar dividend ratios.

Table 1. Statistic descriptions.

\begin{tabular}{cccccc}
\hline & Mean & Median & Std. Dev. & p25 & p75 \\
\hline FV & 0.461 & 0.204 & 0.581 & 0.094 & 0.575 \\
FV_2 & -1.803 & -1.936 & 1.538 & -2.982 & -0.562 \\
ROA & 8.498 & 5.115 & 9.577 & 3.04 & 10.9 \\
Gross & 0.302 & 0.187 & 0.332 & 0.108 & 0.338 \\
OP & 0.122 & 0.085 & 0.123 & 0.049 & 0.143 \\
NET & 0.085 & 0.051 & 0.096 & 0.03 & 0.109 \\
SGA & -0.213 & -0.151 & 0.23 & -0.234 & -0.071 \\
OpCap & 0.567 & 0.698 & 0.752 & 0.38 & 0.911 \\
CapOut & 11.775 & 12.041 & 1.636 & 10.844 & 12.938 \\
Z & 2.594 & 2.265 & 1.347 & 1.57 & 3.38 \\
DPR & 29.57 & 25.935 & 29.051 & 0 & 44.821 \\
\hline
\end{tabular}

This table presents descriptive statistics for the major variables used in the analysis. All continuous variables are winsorized at $1 \%$ and $99 \%$ percentiles. All variables are defined in Appendix A.

Table 2 shows the correlation analysis. It shows that the average firm value (FV) and profitability (ROA) had a correlation of 0.361 and were significant at the $1 \%$ level. This indicates that firms with higher profitability were more likely to have high firm values. Also, similarly positive and significant correlations occurred with other profitability measurements, including the gross, operating, and gross profits. The average firm value (FV) had positive (0.209) and significant correlation with the dividend policy. This implies that the higher ratio of the dividend policy maximized the firm value. Furthermore, other control variables, such as the firm financial expenditure (LnCxp) and financial distress $(\mathrm{Z})$, indicated a positive and significant correlation. By contrast, selling, general, and administration expense (SGA) and abundant cash flow (AbnCFO) showed a positive but insignificant correlation with the firm value.

Table 2. Correlation.

\begin{tabular}{|c|c|c|c|c|c|c|c|c|c|c|c|}
\hline & FV & FV_2 & ROA & Gross & OP & NET & SGA & OpCap & CapOut & $\mathbf{Z}$ & DPR \\
\hline $\mathrm{FV}$ & 1 & & & & & & & & & & \\
\hline FV_2 & $0.209 * *$ & 1 & & & & & & & & & \\
\hline $\mathrm{ROA}$ & $0.361 * * *$ & 0.183 * & 1 & & & & & & & & \\
\hline Gross & $0.219 * *$ & 0.104 & $0.680^{* * *}$ & 1 & & & & & & & \\
\hline $\mathrm{OP}$ & $0.370 * * *$ & $0.171^{*}$ & $0.982 * * *$ & $0.689 * * *$ & 1 & & & & & & \\
\hline NET & $0.362 * * *$ & $0.182 *$ & $1.000^{* * *}$ & $0.680 * * *$ & $0.982 * * *$ & 1 & & & & & \\
\hline SGA & 0.0523 & -0.00905 & 0.148 & $-0.295^{* * *}$ & $0.159 *$ & 0.148 & 1 & & & & \\
\hline OpCap & 0.116 & -0.00811 & $0.160 *$ & 0.169 * & 0.144 & $0.159 *$ & $-0.201 * *$ & 1 & & & \\
\hline CapOut & $0.474 * * *$ & $0.221 * *$ & $0.295^{* * *}$ & $0.273 * * *$ & $0.286^{* * *}$ & $0.294^{* * *}$ & $-0.198^{* *}$ & 0.135 & 1 & & \\
\hline Z & $0.377^{* * *}$ & $0.264^{* * *}$ & $0.286^{* * *}$ & 0.121 & $0.291^{* * *}$ & $0.287^{* * *}$ & $0.260 * * *$ & $0.155^{*}$ & 0.0827 & 1 & \\
\hline DPR & 0.0718 & 0.189 * & 0.169 * & $0.398^{* * *}$ & 0.164 * & 0.169 * & $-0.301^{* * *}$ & 0.0420 & 0.113 & 0.153 * & 1 \\
\hline
\end{tabular}

This table presents the correlations for the major variables used in the analysis. All continuous variables are winsorized at $1 \%$ and $99 \%$ percentiles. All variables are defined in Appendix A. ${ }^{* * *}, * *$, and ${ }^{*}$ denote statistical significance at the $1 \%, 5 \%$, and $10 \%$ levels, respectively. 


\subsection{Baseline Results}

Table 3 presents the baseline regression results of the hypotheses test. The first hypothesis suggests a positive association between profitability and firm value for the SRI-KEHATI firms. Column (1) shows the results from Equation (1) for the profitability and control variables. The coefficient for profitability was positive (0.046) and significant at a $1 \%$ level. In Column (2), Equation (2) was applied by including the profitability, moderator, and control variables, with the results remaining unchanged. Column (3) presents the results from Equation (3) which include the independent variable (profitability), moderator variable (dividend policy), and the interaction between the moderator variable and independent variable. We found that the relationship between the profitability and firm value remained positive (0.04) and significant at the $1 \%$ level. These results confirm the first hypothesis that profitability increases the firm value of SRI-KEHATI-listed firms.

Table 3. Baseline model.

\begin{tabular}{cccc}
\hline & $\mathbf{( 1 )}$ & $\mathbf{( 2 )}$ & $\mathbf{( 3 )}$ \\
& $\mathbf{F V}$ & $\mathbf{F V}$ & $\mathbf{F V}$ \\
\hline ROA & $0.046^{* * *}$ & $0.047^{* * *}$ & $0.04^{* * *}$ \\
& $(0.008)$ & $(0.008)$ & $(0.008)$ \\
DIV & & -0.029 & $-0.104^{* *}$ \\
& & $(0.038)$ & $(0.049)$ \\
ROA*DIV & & $0.008^{* * *}$ \\
& & & $(0.003)$ \\
$\mathrm{Z}$ & $-0.084^{*}$ & $-0.085^{*}$ & $-0.093^{* *}$ \\
& $(0.048)$ & $(0.047)$ & $(0.046)$ \\
CapOut & $0.078^{* * *}$ & $0.081^{* * *}$ & $0.086^{* * *}$ \\
& $(0.021)$ & $(0.022)$ & $(0.022)$ \\
OpCap & -0.005 & -0.006 & -0.007 \\
& $(0.022)$ & $(0.022)$ & $(0.023)$ \\
SGA & $-2.094^{* * *}$ & $-2.085^{* * *}$ & $-2.002^{* * *}$ \\
& $(0.503)$ & $(0.508)$ & $(0.497)$ \\
cons & 0.401 & 0.396 & 0.434 \\
& $(0.381)$ & $(0.38)$ & $(0.372)$ \\
Observations & 170 & 170 & 170 \\
R-squared & 0.855 & 0.856 & 0.859 \\
\hline
\end{tabular}

This table presents a hierarchy regression analysis, examining the relationship between profitability and firm value and the moderating role of dividend policy in the profitability-firm value relationship. All variables are winsorized at $1 \%$ and $99 \%$ percentiles. We used robust standard error clustering at the firm and year in every model. We included industry- and year-fixed effects. Standard errors are in parentheses, with ${ }^{* * *},{ }^{* *}$, and ${ }^{*}$ denoting statistical significance at the $1 \%, 5 \%$, and $10 \%$ levels, respectively. All variables are defined in Appendix A.

Column (3) in Table 3 presents the moderating effect of the dividend policy on the relationship between the profitability and firm value. Following the moderate hierarchy regression, the interaction model in Column (3) was positive (0.008) and significant at a $1 \%$ level, suggesting that the dividend policy was a moderator variable. Equations (2) and (3) were checked to determine whether the dividend policy was a pure or quasi-moderator. Column (2) shows that the dividend policy had a negative (-0.104) and significant (at a $5 \%$ level) relationship with the firm value, but we found that the dividend policy had no significant effect on the firm value in Column (3). This result suggests that the dividend policy plays a role as a pure moderator in the relationship between profitability and firm value.

With respect to the control variables, capital expenditure and selling, general, and administrative expenses influenced the firm value. Financial distress had a marginal effect on firm value because it is not always significant in every model. However, this study could not find a significant impact for firm capability on firm value. 


\subsection{Endogeneity Test}

\subsubsection{Endogeneity: Using Firm Fixed Effect}

The association between profitability and firm value may be biased because of potential endogeneity related to omitted variables and reverse causality. Therefore, three endogeneity tests were performed to address this concern.

Firm fixed-effect regression analysis was used to mitigate the endogeneity caused by omitted variables. The firm-fixed effect addresses the omitted variable bias arising from unobserved heterogeneity (Chi 2005). Aside from the unobserved variable, the authors of Coles and $\mathrm{Li}$ (2016) also suggested that the endogeneity problem may occur because of a CEO's characteristics ${ }^{2}$. The results of using the firm fixed effect to mitigate the endogeneity are presented in Columns (1-3) om Table 4. The sign from the profitability (model 1), dividend policy (model 2), and interaction (model 3) coefficients remained unchanged and consistent, as presented in the baseline model in Table 3.

Table 4. Endogeneity test using firm-fixed effect and using lag of independent variable.

\begin{tabular}{|c|c|c|c|c|c|c|}
\hline & \multicolumn{3}{|c|}{$\begin{array}{l}\text { Using Firm } \\
\text { Fixed Effect }\end{array}$} & \multicolumn{3}{|c|}{$\begin{array}{l}\text { Using Lag } \\
\text { Independent } \\
\text { Variable }\end{array}$} \\
\hline & (1) & (2) & (3) & (4) & (5) & (6) \\
\hline & FV & FV & FV & FV & FV & FV \\
\hline ROA & $\begin{array}{c}0.028^{* * *} \\
(0.005)\end{array}$ & $\begin{array}{c}0.028 * * * \\
(0.005)\end{array}$ & $\begin{array}{c}0.024 * * * \\
(0.005)\end{array}$ & & & \\
\hline ROA_lag & & & & $0.037^{* * *}$ & $0.037^{* * *}$ & $0.032^{* * *}$ \\
\hline DIV & & $\begin{array}{l}-0.014 \\
(0.027)\end{array}$ & $\begin{array}{c}-0.063 \text { * } \\
(0.036)\end{array}$ & & $\begin{array}{l}-0.014 \\
(0.027)\end{array}$ & $\begin{array}{c}-0.063 * \\
(0.036)\end{array}$ \\
\hline ROA*DIV & & & $\begin{array}{c}0.005^{* *} \\
(0.002)\end{array}$ & & & $\begin{array}{c}0.005^{* *} \\
(0.002)\end{array}$ \\
\hline Z & $\begin{array}{c}0.016 \\
(0.037)\end{array}$ & $\begin{array}{c}0.015 \\
(0.037)\end{array}$ & $\begin{array}{c}0.008 \\
(0.037)\end{array}$ & $\begin{array}{l}-0.047 \\
(0.048)\end{array}$ & $\begin{array}{l}-0.047 \\
(0.047)\end{array}$ & $\begin{array}{l}-0.054 \\
(0.046)\end{array}$ \\
\hline CapOut & $\begin{array}{c}0.042 * * * \\
(0.012)\end{array}$ & $\begin{array}{c}0.044^{* * *} \\
(0.013)\end{array}$ & $\begin{array}{c}0.047^{* * *} \\
(0.013)\end{array}$ & $\begin{array}{c}0.083^{* * *} \\
(0.024)\end{array}$ & $\begin{array}{c}0.085^{* * *} \\
(0.024)\end{array}$ & $\begin{array}{c}0.091^{* * *} \\
(0.025)\end{array}$ \\
\hline OpCap & $\begin{array}{l}-0.024 \\
(0.018)\end{array}$ & $\begin{array}{l}-0.025 \\
(0.018)\end{array}$ & $\begin{array}{l}-0.025 \\
(0.019)\end{array}$ & $\begin{array}{l}0.009 \\
(0.02)\end{array}$ & $\begin{array}{l}0.007 \\
(0.02)\end{array}$ & $\begin{array}{l}0.006 \\
(0.02)\end{array}$ \\
\hline SGA & $\begin{array}{l}-0.383 \\
(0.397)\end{array}$ & $\begin{array}{l}-0.37 \\
(0.398)\end{array}$ & $\begin{array}{l}-0.314 \\
(0.389)\end{array}$ & $\begin{array}{c}-1.587^{* * *} \\
(0.495)\end{array}$ & $\begin{array}{c}-1.586^{* * *} \\
(0.501)\end{array}$ & $\begin{array}{c}-1.547 * * * \\
(0.497)\end{array}$ \\
\hline cons & $\begin{array}{c}0.995 * * * \\
(0.264)\end{array}$ & $\begin{array}{c}0.993^{* * *} \\
(0.265)\end{array}$ & $\begin{array}{c}1.024^{* * *} \\
(0.261)\end{array}$ & $\begin{array}{c}0.397 \\
(0.421)\end{array}$ & $\begin{array}{c}0.391 \\
(0.419)\end{array}$ & $\begin{array}{c}0.392 \\
(0.412)\end{array}$ \\
\hline Observations & 170 & 170 & 170 & 153 & 153 & 153 \\
\hline R-squared & 0.93 & 0.931 & 0.932 & 0.846 & 0.847 & 0.849 \\
\hline Firm-fixed effect & YES & YES & YES & & & \\
\hline
\end{tabular}

\subsubsection{Endogeneity: Using a Lag of an Independent Variable}

The second test to mitigate endogeneity between the profitability and firm value used the lag value of a dependent variable (Nagar and Rajan 2001; Miguel et al. 2004; Sohn 2016). The lag value from the ROA was used as an independent variable. Lagged independent variables associate with simultaneity, where the explanatory variable is jointly determined with the dependent variable (Sinkin et al. 2008). The results are presented in Columns (4-6). Similarly, the results were unchanged, as in the main findings in Table 3. The coefficient of profitability and interaction regression remained positive and significant.

\subsubsection{Endogeneity: Using 2SLS}

Following the work in (Chi 2005; Miguel et al. 2004), this study employed two-stage regression (2SLS) to address the possible reverse causality between the firm value and profitability. To perform this test, in the first stage, the ROA was regressed on all exogenous 
variables. The expected value of the ROA from the first stage was used for the main regression in the second stage. In the first stage, we used the market-to-book ratio (MTB), financial distress (Z), capital output (CapOut), operating capability (OpCap), and selling, general, and administrative expense (SGA) as exogenous variables in the first stage. In the second stage, the expected value of the ROA was used, and the regression from Table 3 was repeated. The results are shown in Table 5. Column (1) presents the first stage, while Columns (2-4) present the second stage. In the second stage of regression, the profitability coefficient was positive and significant, similar to the main findings in Table 3. Additionally, the interaction regression showed unchanged findings, as in Table 3. Therefore, the endogeneity issue did not influence the results.

Table 5. Endogeneity test using two-stage least square (2SLS).

\begin{tabular}{|c|c|c|c|c|}
\hline & First Stage & Second Stage & & \\
\hline & (1) & (2) & (3) & (4) \\
\hline & ROA & FV & FV & FV \\
\hline MTB & $\begin{array}{c}283.396^{* * *} \\
(82.519)\end{array}$ & & & \\
\hline $\mathrm{ROA}$ & & $\begin{array}{c}0.083^{* * *} \\
(0.018)\end{array}$ & $\begin{array}{c}0.084^{* * *} \\
(0.019)\end{array}$ & $\begin{array}{l}0.08^{* * *} \\
(0.018)\end{array}$ \\
\hline DIV_w & & & $\begin{array}{c}-0.033 \\
(0.04)\end{array}$ & $\begin{array}{c}-0.115^{* *} \\
(0.052)\end{array}$ \\
\hline ROA_DIV & & & & $\begin{array}{c}0.009^{* * *} \\
(0.003)\end{array}$ \\
\hline $\mathrm{Z}$ & $\begin{array}{l}1.383 * * \\
(0.571)\end{array}$ & $\begin{array}{c}-0.136^{* * *} \\
(0.047)\end{array}$ & $\begin{array}{c}-0.138^{* * *} \\
(0.047)\end{array}$ & $\begin{array}{c}-0.148^{* * *} \\
(0.047)\end{array}$ \\
\hline CapOut & $\begin{array}{c}0.604 * * \\
(0.272)\end{array}$ & $\begin{array}{c}0.055^{* *} \\
(0.027)\end{array}$ & $\begin{array}{l}0.058^{* *} \\
(0.027)\end{array}$ & $\begin{array}{l}0.062 * * \\
(0.027)\end{array}$ \\
\hline OpCap & $\begin{array}{c}0.115 \\
(0.311)\end{array}$ & $\begin{array}{l}-0.009 \\
(0.019)\end{array}$ & $\begin{array}{l}-0.011 \\
(0.019)\end{array}$ & $\begin{array}{l}-0.012 \\
(0.019)\end{array}$ \\
\hline SGA & $\begin{array}{l}-9.539 \\
(8.044)\end{array}$ & $\begin{array}{c}-1.719^{* *} \\
(0.662)\end{array}$ & $\begin{array}{c}-1.702^{* *} \\
(0.668)\end{array}$ & $\begin{array}{c}-1.65^{* *} \\
(0.661)\end{array}$ \\
\hline cons & $\begin{array}{l}-1.574 \\
(4.927)\end{array}$ & $\begin{array}{c}0.452 \\
(0.462)\end{array}$ & $\begin{array}{l}0.448 \\
(0.46)\end{array}$ & $\begin{array}{c}0.472 \\
(0.455)\end{array}$ \\
\hline Observations & 170 & 170 & 170 & 170 \\
\hline R-squared & 0.893 & 0.801 & 0.801 & 0.805 \\
\hline
\end{tabular}

This table presents an endogeneity test using two-stage least square (2SLS). All variables are winsorized at $1 \%$ and $99 \%$ percentiles. We used robust standard error clustering at the firm and year in every model. We included industry- and year-fixed effects. Standard errors are in parentheses, with ${ }^{* * *}$, and ${ }^{* *}$ denoting statistical significance at the $1 \%$ and $5 \%$ levels, respectively. All variables are defined in Appendix A.

\subsection{Robustness Tests}

Several analyses were conducted to verify the results to be considered robust to various changes in variable measurements and conditions.

\subsubsection{Alternative Firm Value Measurements}

We used the log value of the firm's stock price (FV_2) at the end of the year as our alternative firm value measurement, and Columns (1-3) in Table 6 present the results. Profitability had a positive and significant relationship with the firm value in every model, suggesting that a more profitable firm increases its value. With respect to the moderating role of dividend policy, Column (3) shows that the results remained similar to the main findings - positive and significant-with a coefficient of 0.013 and significant at $10 \%$. This implies that the dividend policy is a moderator variable in the relationship between profitability and firm value. We also found that the pure moderator role was applied for the dividend policy, as Column (2) shows. Therefore, the results were robust using alternative measurements of the firm value. 
Table 6. Robustness test using alterative measurement of firm value (FV_2) and alternative dividend policy measurement (DPR).

\begin{tabular}{|c|c|c|c|c|c|c|}
\hline & $\begin{array}{c}\text { (1) } \\
\text { FV_2 }\end{array}$ & $\begin{array}{c}\text { (2) } \\
\text { FV_2 }\end{array}$ & $\begin{array}{c}\text { (3) } \\
\text { FV_2 }\end{array}$ & $\begin{array}{l}\text { (4) } \\
\text { FV }\end{array}$ & $\begin{array}{l}(5) \\
\text { FV }\end{array}$ & $\begin{array}{l}\text { (6) } \\
\text { FV }\end{array}$ \\
\hline ROA & $\begin{array}{c}0.09976^{* * *} \\
(0.01285)\end{array}$ & $\begin{array}{c}0.09978^{* * *} \\
(0.01281)\end{array}$ & $\begin{array}{c}0.08901 \text { *** } \\
(0.01486)\end{array}$ & $\begin{array}{c}0.046^{* * *} \\
(0.008)\end{array}$ & $\begin{array}{c}0.046^{* * *} \\
(0.008)\end{array}$ & $\begin{array}{c}0.044^{* * *} \\
(0.008)\end{array}$ \\
\hline DIV & & $\begin{array}{l}-0.03933 \\
(0.10179)\end{array}$ & $\begin{array}{l}-0.16146 \\
(0.14211)\end{array}$ & & & \\
\hline ROA_DIV & & & $\begin{array}{l}0.01339 * \\
(0.00722)\end{array}$ & & & \\
\hline DPR & & & & & $\begin{array}{l}-0.001 \\
(0.001)\end{array}$ & $\begin{array}{c}-0.002 * \\
(0.001)\end{array}$ \\
\hline DPR_ROA & & & & & & $\begin{array}{l}0.00008^{*} \\
(0.00004)\end{array}$ \\
\hline Z & $-\underset{* *}{0.24606}$ & $-\underset{* *}{0.24657}$ & $-\underset{* *}{0.25941}$ & -0.084 * & -0.076 & -0.07 \\
\hline & $(0.11088)$ & (0.10986) & (0.10935) & $(0.048)$ & $(0.048)$ & $(0.048)$ \\
\hline CapOut & $\begin{array}{c}0.02306 \\
(0.04818)\end{array}$ & $\begin{array}{c}0.02684 \\
(0.04769)\end{array}$ & $\begin{array}{c}0.03578 \\
(0.04843)\end{array}$ & $\begin{array}{c}0.078^{* * *} \\
(0.021)\end{array}$ & $\begin{array}{c}0.078^{* * *} \\
(0.021)\end{array}$ & $\begin{array}{c}0.079 * * * \\
(0.021)\end{array}$ \\
\hline OpCap & $\begin{array}{c}0.12129 \\
(0.07816)\end{array}$ & $\begin{array}{c}0.11923 \\
(0.07732)\end{array}$ & $\begin{array}{c}0.11814 \\
(0.07708)\end{array}$ & $\begin{array}{l}-0.005 \\
(0.022)\end{array}$ & $\begin{array}{l}-0.007 \\
(0.022)\end{array}$ & $\begin{array}{l}-0.006 \\
(0.022)\end{array}$ \\
\hline SGA & $\begin{array}{c}5.26926^{* * *} \\
(1.04394)\end{array}$ & $\begin{array}{c}5.28149 * * * \\
(1.04546)\end{array}$ & $\begin{array}{c}5.41736^{* * *} \\
(1.03072)\end{array}$ & $\begin{array}{c}-2.094^{* * *} \\
(0.503)\end{array}$ & $\begin{array}{c}-2.171^{* * *} \\
(0.503)\end{array}$ & $\begin{array}{c}-2.213 * * * \\
(0.511)\end{array}$ \\
\hline cons & $\begin{array}{l}0.57893 \\
(0.8109)\end{array}$ & $\begin{array}{c}0.57222 \\
(0.80898)\end{array}$ & $\begin{array}{c}0.63436 \\
(0.81061)\end{array}$ & $\begin{array}{c}0.401 \\
(0.381)\end{array}$ & $\begin{array}{c}0.413 \\
(0.378)\end{array}$ & $\begin{array}{l}0.387 \\
(0.38)\end{array}$ \\
\hline Observations & 170 & 170 & 170 & 170 & 170 & 170 \\
\hline R-squared & 0.89175 & 0.89186 & 0.89313 & 0.855 & 0.856 & 0.858 \\
\hline
\end{tabular}

This table presents a robustness test of the profitability-firm value relationship and the moderating role of dividend policy using the log of a firm's stock price at the end of a period (FV_2) as an alternative measurement of the firm value and the dividend payout ratio (DPR) as an alternative dividend policy measurement. All variables are winsorized at $1 \%$ and $99 \%$ percentiles. We used robust standard error clustering at the firm and year in every model. We included industry- and year-fixed effects. Standard errors are in parentheses, with ${ }^{* *}, * *$ and ${ }^{*}$ denoting statistical significance at the $1 \%, 5 \%$, and $10 \%$ levels, respectively. All variables are defined in Appendix A.

\subsubsection{Alternative Dividend Policy Measurements}

Prior studies showed that dividend policy is measured using the payout ratio (Chen and Steiner 1999; Miller and Rock 1985). Subsequently, this study examined the alternative measurement of dividend policy using the dividend payout ratio (DPR). The dividend payout ratio is the ratio of the total dividends to the operating profits (profits before interest and taxes). The results using the DPR as an alternative dividend policy measurement are in Columns (4-6) in Table 6 . When the dividend policy measurement was substituted with the DPR, the results were consistent in every model and confirmed the baseline findings. This suggests that the findings in Table 3 are robust to alternative dividend policy measures.

\subsubsection{Alternative Firm Profitability Measurements}

This study used an alternative measurement of profitability, following the procedure in Liu et al. (2019). Since profitability measurement could be noisy, a better alternative measure free from market mispricing and less subject to earnings manipulation is needed. Based on Liu et al. (2019), this study used three alternatives for profitability measurement, including gross, operating, and net profitability. The results from using these measurements with the hierarchy moderating analysis is presented in Table 7. Columns (1-3) present the results using gross profit, while Columns (4-6) present the hierarchy analysis using operating profit. The alternative net profitability measure is documented in Columns (7-9). The results are consistent in every model when the profitability measurement is substituted with the alternative measures. Furthermore, the effect of various alternative profitability measurements is positive and significant, supporting the baseline results and H1. 
Table 7. Robustness test using alternative measurement of profitability.

\begin{tabular}{|c|c|c|c|c|c|c|c|c|c|}
\hline & $\begin{array}{l}\text { (1) } \\
\text { FV }\end{array}$ & $\begin{array}{l}(2) \\
\text { FV }\end{array}$ & $\begin{array}{l}\text { (3) } \\
\text { FV }\end{array}$ & $\begin{array}{l}(4) \\
\text { FV }\end{array}$ & $\begin{array}{l}\text { (5) } \\
\text { FV }\end{array}$ & $\begin{array}{l}\text { (6) } \\
\text { FV }\end{array}$ & $\begin{array}{l}\text { (7) } \\
\text { FV }\end{array}$ & $\begin{array}{l}\text { (8) } \\
\text { FV }\end{array}$ & $\begin{array}{l}\text { (9) } \\
\text { FV }\end{array}$ \\
\hline Gross & $\begin{array}{c}0.405^{* *} \\
(0.158)\end{array}$ & $\begin{array}{c}0.402 * * \\
(0.159)\end{array}$ & $\begin{array}{c}0.25 * \\
(0.143)\end{array}$ & & & & & & \\
\hline DIV & & $\begin{array}{l}-0.016 \\
(0.041)\end{array}$ & $\begin{array}{c}-0.107 * \\
(0.058)\end{array}$ & & $\begin{array}{l}-0.036 \\
(0.038)\end{array}$ & $\begin{array}{c}-0.106 * * \\
(0.049)\end{array}$ & & $\begin{array}{l}-0.028 \\
(0.038)\end{array}$ & $\begin{array}{c}-0.103^{* *} \\
(0.049)\end{array}$ \\
\hline GROSS*DIV & & & $\begin{array}{c}0.284^{*} \\
(0.15)\end{array}$ & & & & & & \\
\hline $\mathrm{OP}$ & & & & $\begin{array}{c}3.845^{* * *} \\
(0.737)\end{array}$ & $\begin{array}{c}3.854^{* * *} \\
(0.737)\end{array}$ & $\begin{array}{c}3.372 * * * \\
(0.719)\end{array}$ & & & \\
\hline OP*DIV & & & & & & $\begin{array}{c}0.558^{* *} \\
(0.236)\end{array}$ & & & \\
\hline NET & & & & & & & $\begin{array}{c}4.636^{* * *} \\
(0.828)\end{array}$ & $\begin{array}{c}4.637^{* * *} \\
(0.83)\end{array}$ & $\begin{array}{c}3.976^{* * *} \\
(0.796)\end{array}$ \\
\hline $\mathrm{NET}^{*} \mathrm{DIV}$ & & & & & & & & & $\begin{array}{c}0.819 * * * \\
(0.307)\end{array}$ \\
\hline Z & $\begin{array}{c}-0.024 \\
(0.05)\end{array}$ & $\begin{array}{l}-0.024 \\
(0.049)\end{array}$ & $\begin{array}{l}-0.028 \\
(0.049)\end{array}$ & $\begin{array}{l}-0.075 \\
(0.048)\end{array}$ & $\begin{array}{l}-0.076 \\
(0.047)\end{array}$ & $\begin{array}{c}-0.084 \text { * } \\
(0.046)\end{array}$ & $\begin{array}{c}-0.084 * \\
(0.048)\end{array}$ & $\begin{array}{c}-0.085 * \\
(0.047)\end{array}$ & $\begin{array}{c}-0.092 \text { ** } \\
(0.046)\end{array}$ \\
\hline CapOut & $\begin{array}{c}0.107^{* * *} \\
(0.026)\end{array}$ & $\begin{array}{c}0.109^{* * *} \\
(0.026)\end{array}$ & $\begin{array}{c}0.112 * * * \\
(0.026)\end{array}$ & $\begin{array}{l}0.09 * * * \\
(0.021)\end{array}$ & $\begin{array}{c}0.093^{* * *} \\
(0.021)\end{array}$ & $\begin{array}{c}0.098^{* * *} \\
(0.022)\end{array}$ & $\begin{array}{l}0.08^{* * *} \\
(0.021)\end{array}$ & $\begin{array}{c}0.082^{* * *} \\
(0.021)\end{array}$ & $\begin{array}{c}0.088^{* * *} \\
(0.021)\end{array}$ \\
\hline OpCap & $\begin{array}{l}-0.002 \\
(0.021)\end{array}$ & $\begin{array}{l}-0.003 \\
(0.021)\end{array}$ & $\begin{array}{l}-0.002 \\
(0.021)\end{array}$ & $\begin{array}{c}0 \\
(0.021)\end{array}$ & $\begin{array}{l}-0.002 \\
(0.021)\end{array}$ & $\begin{array}{l}-0.002 \\
(0.021)\end{array}$ & $\begin{array}{l}-0.005 \\
(0.022)\end{array}$ & $\begin{array}{l}-0.006 \\
(0.022)\end{array}$ & $\begin{array}{l}-0.007 \\
(0.023)\end{array}$ \\
\hline SGA & $\begin{array}{c}-2.413^{* * *} \\
(0.678)\end{array}$ & $\begin{array}{c}-2.409 * * * \\
(0.683)\end{array}$ & $\begin{array}{c}-2.329^{* * *} \\
(0.66)\end{array}$ & $\begin{array}{c}-2.072 * * * \\
(0.476)\end{array}$ & $\begin{array}{l}-2.06^{* * *} \\
(0.48)\end{array}$ & $\begin{array}{c}-1.996^{* * *} \\
(0.474)\end{array}$ & $\begin{array}{c}-2.11 * * * \\
(0.501)\end{array}$ & $\begin{array}{c}-2.101^{* * *} \\
(0.506)\end{array}$ & $\begin{array}{l}-2.019 * * * \\
(0.495)\end{array}$ \\
\hline cons & $\begin{array}{l}0.201 \\
(0.47)\end{array}$ & $\begin{array}{c}0.2 \\
(0.471)\end{array}$ & $\begin{array}{c}0.228 \\
(0.452)\end{array}$ & $\begin{array}{c}0.114 \\
(0.395)\end{array}$ & $\begin{array}{c}0.108 \\
(0.392)\end{array}$ & $\begin{array}{c}0.152 \\
(0.384)\end{array}$ & $\begin{array}{c}0.379 \\
(0.379)\end{array}$ & $\begin{array}{c}0.374 \\
(0.378)\end{array}$ & $\begin{array}{l}0.411 \\
(0.37)\end{array}$ \\
\hline Observations & 170 & 170 & 170 & 170 & 170 & 170 & 170 & 170 & 170 \\
\hline R-squared & 0.802 & 0.802 & 0.807 & 0.854 & 0.855 & 0.858 & 0.856 & 0.856 & 0.86 \\
\hline
\end{tabular}

This table presents a robustness test of the profitability-firm value relationship and the moderating role of dividend policy using three alterative measurements of profitability: gross profit in Columns (1-3), operating profit in Column (4-6), and net profit in Columns (7-9). All variables are winsorized at $1 \%$ and $99 \%$ percentiles. We used robust standard error clustering at the firm and year in every model. We included industry- and year-fixed effects. Standard errors are in parentheses, with ***,**, and * denoting statistical significance at the $1 \%$, $5 \%$, and $10 \%$ levels, respectively. All variables are defined in Appendix A.

In all models, the interaction between the dividend policy and profitability (Columns (3), (6), and (9)) was positive and significant. This is consistent with the main findings, suggesting that dividend policy plays a role as a moderating variable in the association between profitability and firm value. We also witnessed that dividend policy was a pure moderator, since it did not significantly affect the profitability in Columns (2), (5), and (8). The consistent results using three alternative profitability measurements support the baseline findings in Table 3 and confirm that $\mathrm{H} 2$ was accepted. Therefore, three alternative profitability measures ensured these results were powerful for several alternative measurements.

\subsubsection{Accounting for Size in the Model}

Our baseline model did not incorporate size as potential factor influencing the dividend policy, profitability, and firm value. The authors of Dang et al. (2018) suggested that size plays a role as a key variable and most significant determinant in most studies, like the current study. We posited that firm size could affect the dividend policy, profitability, and firm value, because it can influence how much a company can produce profit and eventually may become one of the main indicators to determine the level of dividend policy distribution to stockholders.

To address this issue, we accounted for size in our model. Size was defined as the log of the total assets, and the results are presented in Table 8. Even though size was not statistically significant in our model, the main result remained unchanged as in the baseline model in Table 3. Profitability had a positive and significant effect on the firm value in each model, and the pure moderating role of the dividend policy was also witnessed as we add size in our model, suggesting that our model was robust to an alternative, different condition. 
Table 8. Robustness test accounting for size in the model.

\begin{tabular}{|c|c|c|c|}
\hline & $\begin{array}{l}\text { (1) } \\
\text { FV }\end{array}$ & $\begin{array}{l}\text { (2) } \\
\text { FV }\end{array}$ & $\begin{array}{l}\text { (3) } \\
\text { FV }\end{array}$ \\
\hline ROA & $\begin{array}{c}0.046^{* * *} \\
(0.008)\end{array}$ & $\begin{array}{c}0.046^{* * *} \\
(0.008)\end{array}$ & $\begin{array}{l}0.04^{* * *} \\
(0.008)\end{array}$ \\
\hline DIV & & $\begin{array}{l}-0.032 \\
(0.038)\end{array}$ & $\begin{array}{c}-0.109^{* *} \\
(0.05)\end{array}$ \\
\hline ROA_DIV & & & $\begin{array}{c}0.008^{* * *} \\
(0.003)\end{array}$ \\
\hline DPR & $\begin{array}{c}-0.087^{*} \\
(0.048)\end{array}$ & $\begin{array}{c}-0.087^{*} \\
(0.047)\end{array}$ & $\begin{array}{c}-0.095 \text { ** } \\
(0.046)\end{array}$ \\
\hline DPR_ROA & $\begin{array}{c}0.076^{* * *} \\
(0.021)\end{array}$ & $\begin{array}{c}0.079 * * * \\
(0.021)\end{array}$ & $\begin{array}{c}0.084^{* * *} \\
(0.021)\end{array}$ \\
\hline Z & $\begin{array}{l}-0.007 \\
(0.022)\end{array}$ & $\begin{array}{l}-0.008 \\
(0.022)\end{array}$ & $\begin{array}{l}-0.009 \\
(0.023)\end{array}$ \\
\hline CapOut & $\begin{array}{c}-2.065^{* * *} \\
(0.503)\end{array}$ & $\begin{array}{c}-2.053^{* * * *} \\
(0.508)\end{array}$ & $\begin{array}{c}-1.965^{* * *} \\
(0.497)\end{array}$ \\
\hline Size & $\begin{array}{c}0.013 \\
(0.016)\end{array}$ & $\begin{array}{c}0.014 \\
(0.015)\end{array}$ & $\begin{array}{c}0.015 \\
(0.015)\end{array}$ \\
\hline cons & $\begin{array}{c}0.255 \\
(0.435)\end{array}$ & $\begin{array}{c}0.238 \\
(0.434)\end{array}$ & $\begin{array}{c}0.262 \\
(0.426)\end{array}$ \\
\hline Observations & 170 & 170 & 170 \\
\hline R-squared & 0.856 & 0.856 & 0.86 \\
\hline
\end{tabular}

This table presents a robustness test of the profitability-firm value relationship and the moderating role of the dividend policy by incorporating size in each model. All variables are winsorized at $1 \%$ and $99 \%$ percentiles. We used robust standard error clustering at the firm and year in every model. We included industry-and year-fixed effects. Standard errors are in parentheses, with ${ }^{* * *},{ }^{* *}$, and ${ }^{*}$ denote statistical significance at the $1 \%, 5 \%$, and $10 \%$ levels, respectively. All variables are defined in Appendix A.

\subsection{Additional Analysis}

The baseline model in this study did not account for specific conditions influencing firm value. This was because different conditions of a company or factors from another country may have affected shareholder value creation and given different results in our proposed model. Therefore, we examined our model in three different conditions that might occur and need more assessment of their effect on firm value.

\subsubsection{Sub-Sample from a High- vs. Low-Leverage Firm}

This section discusses the leverage conditions of the firms. Previous studies showed that leverage affects firm value (Miller and Rock 1985). This is because a firm with high leverage is required to pay a high fixed expense, such as interest, and potentially deal with higher risk. Therefore, a firm's capability to create shareholder value becomes less effective in a high-leverage firm. Therefore, this study predicts that the direct effect of profitability on firm value is more pronounced with low-leverage firms.

With respect to the moderating role of dividend policy in the profitability-firm value relationship, we suggest two explanations for this relationship. First, dividend policy may substantially affect profitability-firm value linkage in low-leverage firms. In line with agency theory, the agency cost in a low-leverage firm is lower than in high-leverage firms, causing higher rationing of the dividend policy in low-leverage firms than in highleverage firms. Therefore, the effect of the dividend policy on the firm value is more pronounced in low-leverage firms. In contrast, following trade-off theory, the dividend policy's moderating effect could be stronger in high-leverage firms. A leverage ratio below the optimum level results in an enormous tax shield and enhances the firm value. In this case, the dividend policy has a more significant effect on a firm with higher leverage. 
The sample in this study was divided into two sub-samples-high- and low-leverage firms-based on their leverage level to explain this connectio ${ }^{3}$. We define leverage as the total debt scale over the total assets. To determine the high- and low-leverage firms, the sample was divided into 10 decile groups. The first through the fifth decile groups comprised low-leverage firms, while the sixth through tenth decile groups consisted of high-leverage firms. We reexamined the analysis using Equations (1)-(3) in each group. The results are in Table 9.

Table 9. Additional analysis of high- vs. low-leverage firms and high vs. low advertising intensity firms.

\begin{tabular}{|c|c|c|c|c|c|c|c|c|c|c|c|c|}
\hline & \multicolumn{3}{|c|}{ High Lev } & \multicolumn{3}{|c|}{ Low Lev } & \multicolumn{3}{|c|}{ High Advertising Intensity } & \multicolumn{3}{|c|}{ Low Advertising Intensity } \\
\hline & (1) & (2) & (3) & (4) & (5) & (6) & (7) & (8) & (9) & (10) & (11) & (12) \\
\hline & FV & FV & FV & FV & FV & FV & FV & FV & FV & FV & FV & FV \\
\hline ROA & $\begin{array}{l}0.012 * \\
(0.006)\end{array}$ & $\begin{array}{l}0.011 * \\
(0.006)\end{array}$ & $\begin{array}{l}0.011 * \\
(0.006)\end{array}$ & $\begin{array}{c}0.032 * * * \\
(0.006)\end{array}$ & $\begin{array}{c}0.032 * * * \\
(0.006)\end{array}$ & $\begin{array}{l}0.02 * * \\
(0.009)\end{array}$ & $\begin{array}{c}0.008 \\
(0.005)\end{array}$ & $\begin{array}{c}0.007 \\
(0.005)\end{array}$ & $\begin{array}{c}0.005 \\
(0.006)\end{array}$ & $\begin{array}{c}0.068^{* * *} \\
(0.01)\end{array}$ & $\begin{array}{c}0.068^{* * *} \\
(0.01)\end{array}$ & $\begin{array}{c}0.059 * * * \\
(0.01)\end{array}$ \\
\hline DIV & & 0.035 & 0.033 & & -0.05 & $-\underset{* *}{0.167}$ & & 0.032 & 0.006 & & 0.04 & -0.08 \\
\hline $\mathrm{ROA}^{*} \mathrm{DIV}$ & & $(0.023)$ & $\begin{array}{l}(0.031) \\
0.0002 \\
(0.002)\end{array}$ & & $(0.05)$ & $\begin{array}{l}(0.079) \\
0.014^{*} \\
(0.008)\end{array}$ & & $(0.023)$ & $\begin{array}{c}(0.025) \\
0.004 \\
(0.003)\end{array}$ & & $(0.065)$ & $\begin{array}{c}(0.088) \\
0.012 * * \\
(0.005)\end{array}$ \\
\hline Z & $0.144^{* *}$ & $0.145^{* *}$ & $0.144^{* *}$ & 0.015 & 0.014 & 0.007 & 0.017 & 0.023 & 0.019 & $-\underset{* *}{0.155}$ & $\underset{* *}{-0.159}$ & $-\underset{* * *}{0.175}$ \\
\hline & $(0.058)$ & $(0.058)$ & $(0.058)$ & $(0.035)$ & $(0.033)$ & $(0.033)$ & $(0.02)$ & $(0.022)$ & $(0.021)$ & $(0.064)$ & $(0.066)$ & $(0.064)$ \\
\hline CapOut & $\begin{array}{c}0.029 * * * \\
(0.01)\end{array}$ & $\begin{array}{c}0.024^{* *} \\
(0.01)\end{array}$ & $\begin{array}{c}0.024^{* *} \\
(0.01)\end{array}$ & $\begin{array}{c}0.077^{* *} \\
(0.032)\end{array}$ & $\begin{array}{c}0.081 \text { ** } \\
(0.032)\end{array}$ & $\begin{array}{c}0.082^{* * *} \\
(0.031)\end{array}$ & $\begin{array}{c}0.048^{* * *} \\
(0.015)\end{array}$ & $\begin{array}{c}0.044^{* * *} \\
(0.015)\end{array}$ & $\begin{array}{c}0.045^{* * *} \\
(0.015)\end{array}$ & $\begin{array}{c}0.049^{* *} \\
(0.024)\end{array}$ & $\begin{array}{l}0.044^{*} \\
(0.026)\end{array}$ & $\begin{array}{l}0.051 \text { * } \\
(0.026)\end{array}$ \\
\hline OpCap & $\begin{array}{c}0.004 \\
(0.019)\end{array}$ & $\begin{array}{c}0.008 \\
(0.018)\end{array}$ & $\begin{array}{c}0.008 \\
(0.019)\end{array}$ & $\begin{array}{c}-0.046^{*} \\
(0.027)\end{array}$ & $\begin{array}{l}-0.045 \\
(0.028)\end{array}$ & $\begin{array}{l}-0.047 \\
(0.031)\end{array}$ & $\begin{array}{l}-0.003 \\
(0.011)\end{array}$ & $\begin{array}{l}-0.003 \\
(0.011)\end{array}$ & $\begin{array}{l}-0.002 \\
(0.011)\end{array}$ & $\begin{array}{c}-0.06 \\
(0.051)\end{array}$ & $\begin{array}{l}-0.055 \\
(0.053)\end{array}$ & $\begin{array}{l}-0.062 \\
(0.061)\end{array}$ \\
\hline SGA & 0.117 & 0.049 & 0.047 & -0.942 & -0.967 & -0.651 & 1.037 & 1.024 & 1.116 & $\begin{array}{c}-3.262 \\
* * *\end{array}$ & -3.273 & -3.074 \\
\hline cons & $\begin{array}{c}(0.267) \\
-0.125 \\
(0.28)\end{array}$ & $\begin{array}{c}(0.288) \\
-0.09 \\
(0.28)\end{array}$ & $\begin{array}{c}(0.293) \\
-0.088 \\
(0.282)\end{array}$ & $\begin{array}{c}(0.659) \\
0.318 \\
(0.473)\end{array}$ & $\begin{array}{c}(0.661) \\
0.331 \\
(0.467)\end{array}$ & $\begin{array}{c}(0.676) \\
0.472 \\
(0.453)\end{array}$ & $\begin{array}{c}(0.772) \\
1.599 * * * \\
(0.319)\end{array}$ & $\begin{array}{c}(0.789) \\
1.606^{* * *} \\
(0.316)\end{array}$ & $\begin{array}{c}(0.751) \\
1.637^{* * *} \\
(0.304)\end{array}$ & $\begin{array}{c}(0.829) \\
0.419 \\
(0.509)\end{array}$ & $\begin{array}{c}(0.847) \\
0.437 \\
(0.513)\end{array}$ & $\begin{array}{c}(0.822) \\
0.537 \\
(0.501)\end{array}$ \\
\hline Observations & 80 & 80 & 80 & 80 & 80 & 80 & 85 & 85 & 85 & 85 & 85 & 85 \\
\hline R-squared & 0.935 & 0.937 & 0.937 & 0.932 & 0.933 & 0.935 & 0.98 & 0.981 & 0.981 & 0.873 & 0.873 & 0.88 \\
\hline
\end{tabular}

This table presents an additional test of the profitability-firm value relationship and the moderating role of dividend policy by dividing the sample into two sub-sample categories. The first category is the sub-sample from high-vs. low-leverage firms, and the second category is the sub-sample from high vs. low advertising intensity firms. All variables are winsorized at $1 \%$ and $99 \%$ percentiles. We used robust standard error clustering at the firm and year in every model. We included industry- and year-fixed effects. Standard errors are in parentheses, with ***,**, and * denoting statistical significance at the $1 \%, 5 \%$, and $10 \%$ levels, respectively. All variables are defined in Appendix A.

Columns (1-3) of Table 9 show the results from high-leverage firms, while Columns (4-6) represent the results from low-leverage firms. Table 9 shows that the profitability coefficient for high-leverage firms was lower in every model than in low-leverage firms. This indicates that the direct effect of profitability on firm value was more pronounced in low-leverage firms. In addition, we found that dividend policy played a moderating role in both sub-sample firms, since both sub-samples evidenced significant interaction in the third model in Columns (3) and (6). However, the interaction coefficient was higher in the low-leverage firms than in the high-leverage firms, suggesting that the moderating effect of dividend policy was more pronounced in low-leverage firms. Following these results, we supported the agency cost theory perspective for explaining the role of dividend policy in the profitability-firm value relationship in different leverage conditions.

\subsubsection{Sub-Sample from High vs. Low Advertising Intensity Firms}

The baseline model in Table 3 shows that the advertising intensity, proxied by SGA, indicated a positive and significant relationship with the firm value. However, literature reviews from prior studies (Hu et al. 2018) showed that high advertising intensity lowers firm value creation. This is because such high levels of advertising, such as advertising for CSR activities, covers up the firm's inappropriate conduct, leading to a negative stakeholder response. It is also possible that external stakeholders, such as suppliers and customers, do not account for the true benefit of CSR activities. This makes high advertising intensity receive a negative response from the market and lower the firm value. In addition, shareholder and market participants who give concern to a SRI-KEHATI-listed firm's performance is typical of investors that consider sustainable (social and environmental) 
and responsible issues as the primary determinants of firm value creation. They realize the true benefit of these factors, indicating that firms do not need to spend much on advertising intensity. Consequently, high advertising intensity is not considered as an essential value creation factor for SRI-KEHATI firms. In this case, the high advertising intensity firm suffers from a lower firm value than the low-intensity firm. Therefore, it is expected that the effect of dividend policy on the profitability-firm value relationship is more pronounced in low-intensity firms than in high advertising intensity firms.

This study addressed this concern by dividing the sample into two sub-samples based on their SGA levels to determine whether a firm had a high or low advertising intensity. The first through the fifth decile groups comprised low advertising intensity firms, and the remaining groups were high advertising intensity firms. We re-examined the analysis using Equations (1)-(3) in each group. The estimation was supported when the coefficient in low advertising intensity firms was higher than in the high advertising intensity firms. The results are in Table 8.

Columns (7-9) in Table 9 show the results from high advertising intensity firms and, the remaining columns are the results from low advertising intensity firms. Again, as we expected, the profitability coefficient for the high advertising intensity firms in every model (Columns (7-9)) were lower than in the low-leverage firms (Columns (10-12)), implying that the direct effect of profitability on the firm value was more pronounced in low-leverage firms. As we predicted, the interaction coefficient in Column (12) was higher and more significant than that in Column (9). This implies that the moderating role of dividend policy in profitability-firm value relationships is more pronounced in low advertising intensity firms.

4.5.3. Pre- and Post-Dividend Payment Regulation from the Financial Services Authority of Indonesia

The Financial Services Authority of Indonesia, or Otoritas Jasa Keuangan (OJK), issued regulation No. 32/POJK.04/2014, requiring a public company to pay a dividend at least 30 days after the announcement to the public. We suggest that the regulation may influence a firm's dividend policy and value, because firms need to carefully consider their dividend policy ratio and have sufficient cash on hand to pay the dividend. Therefore, this regulation may have a potential effect on the dividend policy and firm value. Therefore, we predicted that the moderating role of dividend policy would be more pronounced on post-regulation to indicate that the dividend payment regulation contributed to the firm's dividend policy.

We examined this concern by dividing the period into two sub-sample periods. Predividend payment regulation fell between 2010 and 2014, while post-dividend regulation fell between 2015 and 2019. The interaction coefficient in the post-regulation period was expected to be higher than in the pre-regulation period to support our prediction. The results are shown in Table 10. Columns (1-3) in Table 10 show the results from postdividend payment regulation, while Columns (4-6) indicate the pre-dividend payment regulation. The coefficient in Column (3) is positive ( 0.01 ) and significant at $10 \%$. In contrast, the interaction coefficient in Column (6) is insignificant. This implies that the moderating role of dividend policy was more pronounced in post-regulation than in pre-regulation. Therefore, this finding supports our prediction. 
Table 10. Pre- and post-dividend payment regulation.

\begin{tabular}{ccccccc}
\hline & Post & \multicolumn{5}{c}{ Pre } \\
\hline & $\mathbf{( 1 )}$ & $\mathbf{( 2 )}$ & $\mathbf{( 3 )}$ & $\mathbf{( 4 )}$ & $\mathbf{( 5 )}$ & $\mathbf{( 6 )}$ \\
& $\mathbf{F V}$ & $\mathbf{F V}$ & $\mathbf{F V}$ & $\mathbf{F V}$ & $\mathbf{F V}$ & $\mathbf{F V}$ \\
\hline ROA & $0.011^{* *}$ & $0.011^{* *}$ & 0.004 & $0.065^{* * *}$ & $0.066^{* * *}$ & $0.062^{* * *}$ \\
& $(0.004)$ & $(0.003)$ & $(0.004)$ & $(0.007)$ & $(0.007)$ & $(0.007)$ \\
DIV & & -0.103 & $-0.151^{*}$ & & 0.08 & 0.023 \\
& & $(0.056)$ & $(0.07)$ & & $(0.064)$ & $(0.098)$ \\
ROA*DIV & & & $0.01^{*}$ & & & 0.005 \\
& & & $(0.004)$ & & & $(0.004)$ \\
Z & -0.055 & $-0.056^{* * *}$ & $-0.061^{* *}$ & $-0.196^{* *}$ & $-0.197 * *$ & $-0.2 * *$ \\
& $(0.032)$ & $(0.017)$ & $(0.018)$ & $(0.064)$ & $(0.06)$ & $(0.055)$ \\
CapOut & $0.126^{* * *}$ & $0.133^{* * *}$ & $0.135^{* * *}$ & 0.04 & 0.037 & 0.04 \\
& $(0.009)$ & $(0.01)$ & $(0.013)$ & $(0.025)$ & $(0.023)$ & $(0.025)$ \\
OpCap & -0.008 & -0.009 & -0.009 & 0.052 & 0.061 & 0.056 \\
& $(0.019)$ & $(0.023)$ & $(0.024)$ & $(0.054)$ & $(0.051)$ & $(0.053)$ \\
SGA & $-1.889 * *$ & $-2.076^{* *}$ & $-2.005^{* *}$ & $-2.836^{* * *}$ & $-2.92 * * *$ & $-2.832 * * *$ \\
& $(0.569)$ & $(0.546)$ & $(0.523)$ & $(0.37)$ & $(0.476)$ & $(0.49)$ \\
cons & -0.018 & -0.082 & -0.046 & 1.043 & 0.963 & 1.009 \\
& $(0.291)$ & $(0.292)$ & $(0.321)$ & $(0.596)$ & $(0.581)$ & $(0.59)$ \\
Observations & 85 & 85 & 85 & 85 & 85 & 85 \\
R-squared & 0.902 & 0.909 & 0.91 & 0.893 & 0.895 & 0.895
\end{tabular}

This table presents an additional test of the profitability-firm value relationship and the moderating role of dividend policy by dividing a sample into two periods. The first sub-sample is from the period after the dividend payment regulation, which fell between 2010 and 2014 (pre-regulation period), and the second sub-sample is from the period before the dividend payment regulation, which fell between 2015 and 2019 (post-regulation period) All variables are winsorized at $1 \%$ and $99 \%$ percentiles. We used robust standard error clustering at the firm and year in every model. We included industry- and year-fixed effects. Standard errors are in parentheses, with ${ }^{* * *}$ **, and * denote statistical significance at the $1 \%, 5 \%$, and $10 \%$ levels, respectively. All variables are defined in Appendix A.

\section{Discussion}

This section provides discussion of the findings from the regression results in the previous section. The baseline model results show that profitability positively affected the firm value. This means that more profitability enhanced the shareholder value in the SRI-KEHATI firms, supporting the first hypothesis. We provided several explanations for justifying the first finding. SRI-KEHATI firms present good financial performance, such as producing high profitability, encouraging people to invest more in STI-KEHATI firms. Producing high profitability may promote the firm to distribute more dividends, causing higher share prices and enhancing the firm's value. This argument is supported by prior studies, which found that dividend policy could be considered by the market as a positive signal of a firm's future performance (Bhattacharya 1979; Theodoulou et al. 2010; Skinner and Soltes 2011; Miller and Rock 1985) and increase the firm value. This study also suggests that the positive association between profitability and firm value may occur because the company creates operating efficiency, producing more profit and experiencing higher firm value. This is in line with the prior literature, which documented that a firm's efficiency positively impacts value (He and Chen 2007; Sohn 2016). Receiving trust from capital market investors may also possibly explain this positive association. Since firms listed as SRI-KEHATI firms have specific environmental and sustainability concerns, this concern encourages investors to put more trust in SRI-KEHATI firms. Therefore, a higher firm value seems possible to achieve for SRI-KEHATI firms. Our argument is also in line with prior studies, which found that CSR positively impacts firm value (Abdi et al. 2020; Kong et al. 2019). Therefore, this study is consistent with Salvi et al. (2021), Chen and Chen (2011), and Liow (2010), which suggested a positive association between profitability and firm value.

We evidenced that dividend policy is a pure moderator of the relationship between profitability and firm value, suggesting that it plays a role as a moderator variable but not 
as an independent variable. These findings support the second hypothesis, implying that the positive association between profitability and firm value is strengthened by dividend policy. One possible explanation is that when the dividend policy is announced to the public, it can decrease the information asymmetry between management and shareholders. Furthermore, it may increase the market value of shares, leading to higher company value (Faccio et al. 2001; Gomes 2000). In addition, a dividend can be used as a reward for investors or to maximize the firm value. It can also be considered a positive signal of a firm's future performance, which may lead to a higher share price and value (Kim et al. 2021; Theodoulou et al. 2010; Skinner and Soltes 2011). Lastly, SRI-KEHATI shareholders and investors have more concern for environmental and sustainability problems. They are less likely to consider dividend policy as a single driving factor when accounting for firm value creation. They are more likely to consider sustainable and responsible concern as a primary factor in enhancing the firm value, causing dividend policy to become a pure moderator variable. When a firm produces high profit, the firm value increases, and this positive association becomes stronger when a company provides a higher dividend ratio for its shareholders. All primary findings are robust to specific alternative variable measurements and conditions, and we documented that endogeneity did not influence our results.

In addition to the main findings, we revealed another interesting piece of evidence. The moderating effect of the dividend policy in the profitability-firm value association was more pronounced in low-leverage than in high-leverage firms. This result supports the agency cost theory, suggesting that low-leverage firms experience lower agency costs than high-leverage firms, causing firms to produce more profit. Therefore, the firm will gain higher profitability and a greater ratio of dividends, allowing an increase in firm value. Prior studies support the findings that low-leverage firms may contribute to firm value creation (Miller and Rock 1985). We further examined whether the effect of the dividend policy on the profitability-firm value relationship was more pronounced in low than in high advertising intensity firms. We found that low advertising intensity firms experienced a more pronounced effect from the moderating role of dividend policy on profitability-firm value relationships. This supports the argument that high advertising intensity is not always a promising strategy for boosting a firm's value. In contrast, it may harm the firm value creation. Moreover, in more social, environmental, and sustainability concerned firms such as SRI-KEHATI firms, such expenses may become less important to create firm value and less essential in increasing firm value. This is because shareholders and stakeholders give much credit to a firm without many expenses in advertising. These findings support the results in $\mathrm{Hu}$ et al. (2018).

Lastly, to examine whether there was an impact of the country factor on the moderating role of dividend policy, we reinvestigated our model in the pre- and post-dividend policy payment regulation periods from the Financial Services Authority of Indonesia. We found that the moderating role of dividend policy was more pronounced in the post-regulation period than in the pre-regulation period, suggesting that dividend payment regulation from the Financial Services Authority of Indonesia contributes to dividend policy decisions. This result indicates that country regulation affects the firm's strategic decision, especially with respect to the dividend policy.

\section{Conclusions}

This study examined the relationship between profitability and firm value and the moderating effect of dividend policy on this association in SRI-KEHATI firms in the Indonesian capital market. Using moderate hierarchy analysis, the results show that profitability is a positive factor that enhances a firm's value. We also documented that the association between profitability and firm value is positively moderated by dividend policy as a pure moderator. This analysis was free from the endogeny problem overlooked by most prior studies, causing biased results and interpretation. While the main finding was robust to several alternatives of variable measurements, there were also additional results. The moderating effect of the dividend policy in profitability-firm value linkage was more 
pronounced in low- than high-leverage firms, supporting the agency cost hypothesis. Additionally, low advertising intensity firms experienced a more pronounced effect from the moderating role of dividend policy. This supports the negative role of advertising intensity in firm value creation. We evidenced that the post-dividend payment regulation from the Financial Services Authority of Indonesia essentially contributes to the firm's dividend policy decision. The findings shed light on how dividend policy and profitability are essential factors for firm value maximization in a more sustainable and social environment.

This study provides some practical implications for investors, management of a company, and regulators. First, as we evidenced significant findings on dividend policy regulation issued by the Financial Services Authority, Indonesian capital market regulators can better understand that dividend policy regulation can affect firm value creation, and further regulation and capital market policy with respect to dividend policy should be issued with more caution. Second, our findings are important for Indonesian SRI-KEHATI investors and shareholders because they may consider dividend policy and profitability as a promising determinant combination and a signal for them when assessing the performance of SRI firms. Third, we also suggest that our finding is essential for decision makers of a company when they set a regulation on the dividend policy, as it may become a potential strategy to inflate the value of their firms.

We should address several limitations in the current study. First, we used only firms that were listed as sustainable and responsible investment firms. Therefore, our findings could not generalize any samples other than SRI-listed firms. It would be interesting to extend the evidence by adding the SRI-listed firm samples from other countries and examine whether dividend policy had an impact on the profitability-firm value relationship in a larger sample from the international capital market. Using international data to examine current studies may also allow for making a comparison between countries or legal systems to obtain deeper and richer explanations on dividend policy's role as a moderating variable. Second, studies in firm value creation have shown that various non-financial variables, such as managerial characteristics and corporate governance, may have an important role in determining the value of a firm. We did not consider these non-financial variables in the relationship between profitability and firm value. It would be worthwhile to consider non-financial determinants of firm value for this issue. Third, as suggested in Coles and Li (2016), the endogeneity issue may rise from a CEO's characteristics, and the current study suffered from this limitation because we did not consider this variable in our endogeneity test due to data availability. Future research may expand the current study by including the CEO's characteristics in the endogeneity test to provide more complete analysis.

Author Contributions: A.A. contributed to conceptualization, formal analysis, writing of the original draft, and review and editing. Y.J. contributed to the formal analysis, methodology, data examination, writing of the original draft, and review and editing. All authors have read and agreed to the published version of the manuscript.

Funding: This research was funded by a grant from Research and Community Service Internal Funding of University of Sultan Ageng Tirtayasa. Grant number: 201/UN43/KPT.PT.01.

Data Availability Statement: Data will be available on request.

Conflicts of Interest: The authors declare no conflict of interest. 


\section{Appendix A. Variable Definition and Measurement}

\begin{tabular}{|c|c|}
\hline Variables & Description and Measurement \\
\hline \multicolumn{2}{|l|}{ Dependent Variable } \\
\hline Firm value (FV) & $\begin{array}{l}\text { - The average of the shares' high and low market prices or average share price (FV) (baseline test) } \\
\text { - } \quad \text { Log of firm's share price at the end of the year (FV_2) (robustness test) }\end{array}$ \\
\hline $\begin{array}{l}\text { Independent Variables } \\
\text { Profitability: Return on assets (ROA) } \\
\text { Profitability: Gross profit (Gross) } \\
\text { Profitability: Operating profit (OP) } \\
\text { Profitability: net profit (NET) }\end{array}$ & $\begin{array}{l}\text { Return on assets (ROA) measured by using the EBIT/TA ratio for firm } \mathrm{i} \text { in year } \mathrm{t} \text { (baseline test) } \\
\text { The gross profit scale by total assets (REVT - COGS) / AT (robustness test) } \\
\text { Operating profit scale by total assets, or (OIBDP)/AT (robustness test) } \\
\text { Net income scale by total assets (NI)/AT (robustness test) }\end{array}$ \\
\hline \multicolumn{2}{|l|}{ Moderating Variable } \\
\hline Dividend policy (DP) & $\begin{array}{l}\text { - } \quad \text { Dummy variable indicating } 1 \text { for firm which pays dividends and } 0 \text { otherwise (baseline test) } \\
\text { Measured by dividend payout ratio (DPR), defines as earnings per share deflated by dividend per } \\
\text { share (robustness test) }\end{array}$ \\
\hline \multicolumn{2}{|l|}{ Control Variable (CV) } \\
\hline Financial distress $(\mathrm{Z})$ & Measured by Z score from Osiris database \\
\hline Capital output (CapOut) & Measured by natural log values from capital expenditure at the end of the year \\
\hline Operating capability (OpCap) & $\begin{array}{l}\text { Measured by cash flow abundance, defines as net measured by operating cash flow normalized by total } \\
\text { operating revenue }\end{array}$ \\
\hline Advertising intensity (SGA) & Measured by firm's selling, general, and administration expense (SGA) \\
\hline
\end{tabular}

\section{Notes}

1 The authors of (Dang et al. 2018) showed that dividend policy could be negatively related to firm value. When most of the profit funds a firm's growth, the shareholders obtain a minor portion from its shares. The firm value may decrease because a shareholder feels that their investment fails to provide high value. Another explanation was provided by the authors of (D'Amato and Falivena 2020). They suggest that the loss ratio on the dividend policy would be applied for growing firms. This is because most of the firm's profitability is invested in profitable investments to expand the company's business. Although the ratio on the dividend policy is smaller, a shareholder gains additional return besides capital, creating higher firm value. This means that a lower ratio of the dividend policy increases the firm value, suggesting a negative relationship.

2 Because of the limitation of the datasource, we did not include the CEO characteristics in our endogeneity test or in our model.

3 We excluded one sample to perform this analysis because the leverage firm data was not complete. The final total sample for high vs. low leverage firm analysis will result in 160 firm years of observation from 16 companies.

\section{References}

Abdi, Yoghuob, Xiaoni Li, and Xavier Caàmara-Turull. 2020. Impact of Sustainability on Firm Value and Financial Performance in the Air Transport Industry. Sustainability 12: 9957. [CrossRef]

Ahmed, Kamra, and Haim Falk. 2006. The value relevance of management's research and development reporting choice: Evidence from Australia. Journal of Accounting and Public Policy 25: 231-64. [CrossRef]

Ararat, Melsa, Bernard. S. Black, and B. Burcin Yurtoglu. 2017. The effect of corporate governance on firm value and profitability: Time-series evidence from Turkey. Emerging Markets Review 30: 113-32. [CrossRef]

Ardila, Lisa Nuradila, Dany Ady Saputra, Arum Kusumaningdyah Adiati, and Bambang Sutopo. 2018. Asset productivity, profitability, and firm value: Can state-owned companies outperform non-state-owned companies? International Journal of Business and Society 19: 639-50.

Bedford, Anna, Le Ma, Nelson Ma, and Kristina Vojvoda. 2021. Future profitability and stock returns of innovative firms in Australia. Pacific-Basin Finance Journal 66: 101508. [CrossRef]

Benlemlih, Mohammed. 2019. Corporate social responsibility and dividend policy. Research in International Business and Finance 47: 114-38. [CrossRef]

Bhattacharya, Sudipto. 1979. Corporation Imperfect information, dividend policy, and 'the bird in the hand' fallacy. The Bell Journal of Economics 10: 259-70. [CrossRef]

Brigham, Eugene F., and Louis C. Gapenski. 2006. Financial Management: Theory and Practice, 9th ed. Orlando: Harcourt College Publisher.

Bukit, Rina Br, B. Haryanto, and P. Ginting. 2018. Environmental performance, profitability, asset utilization, debt monitoring and firm value. IOP Conference Series: Earth and Environmental Science 122: 012137. [CrossRef]

Chen, Carl R., and Thomas L. Steiner. 1999. Managerial ownership and agency conflicts: A non-linear simultaneous equation analysis of managerial ownership, risk taking, debt policy, and dividend policy. The Financial Review 34: 119-36. [CrossRef] 
Chen, Jihui, and George Waters. 2017. Firm efficiency, advertising and profitability: Theory and evidence. The Quarterly Review of Economics and Finance 63: 240-48. [CrossRef]

Chen, $\mathrm{Li} \mathrm{Ju}$, and Shun-Yu Chen. 2011. The influence of profitability on firm value with capital structure as the mediator and firm size and industry as moderators. Investment Management and Financial Innovations 8: 1231-129.

Chi, Jianxin. 2005. Understanding the Endogeneity between Firm Value and Shareholder Rights. Financial Management 34: 65-76. [CrossRef]

Chia, Yee-Ee, Kian-Ping Lim, and Kim-Leng Goh. 2020. Liquidity and firm value in an emerging market: Nonlinearity, political connections and corporate ownership. The North American Journal of Economics and Finance 52: 101169. [CrossRef]

Chune, Chune Young, Sang Jung, and Jason Young. 2018. Do CSR Activities Increase Firm Value? Evidence from the Korean Market. Sustainability 10: 3164. [CrossRef]

Cleary, Sean. 1999. The relationship between firm investment and financial status. The Journal of Finance 54: 673-92. [CrossRef]

Cohen, Jacob, Cohen Patricia, Stephen G. West, and Leona S. Aiken. 1975. Applied Multiple Regression/Correlation Analysis for the Behavioural Sciences. Hillsdale: Lawrence Erlbaum Associates. [CrossRef]

Coles, Jeffrey L., and Zhichuan Frank Li. 2016. An Empirical Assessment of Empirical Corporate Finance. Business Publications, 23. Available online: https:/ /ir.lib.uwo.ca/iveypub/23 (accessed on 20 August 2021).

D'Amato, Antonia, and Camilla Falivena. 2020. Corporate social responsibility and firm value: Do firm size and age matter? Empirical evidence from European listed companies. Corporate Social Responsibility and Environmental Management 27: 909-24. [CrossRef]

Dang, Chongyu, Zhichuan (Frank) Li, and Chen Yang. 2018. Measuring Firm Size in Empirical Corporate Finance. Journal of Banking $\mathcal{E}$ Finance 86: 159-76.

Endri, Endry, and Moch Fathony. 2020. Determinants of firm's value: Evidence from the financial industry. Management Science Letters 10: 111-20. [CrossRef]

Faccio, Marra, Larry H. Lang, and Leslie Young. 2001. Dividends and Expropriation. The American Economic Review 91: 54-78. [CrossRef]

Fairchild, Richard J., Yilmaz Guney, and Yordying Thanatawee. 2014. Corporate dividend policy in Thailand: Theory and evidence. International Review of Financial Analysis 31: 129-51. [CrossRef]

Fauver, Larry, Mingyi Hung, Xi Li, and Alvafo G. Taboada. 2017. Board reforms and firm value: Worldwide evidence. Journal of Financial Economics 125: 120-42. [CrossRef]

Ghalandari, Kamal. 2013. The moderating effects of growth opportunities on the relationship between capital structure and dividend policy and ownership structure with firm value in Iran: Case study of Tehran securities exchange. Research Journal of Applied Sciences, Engineering and Technology 5: 1424-31. [CrossRef]

Gomes, Armando. 2000. Going Public without Governance: Managerial Reputation Effects. The Journal of Finance 55: 615-46. Available online: http:/ / www.jstor.org/stable/222517 (accessed on 4 July 2021). [CrossRef]

Han, Bong H., and David Manry. 2004. The value-relevance of R\&D and advertising expenditures: Evidence from Korea. The International Journal of Accounting 39: 155-73. [CrossRef]

Handoko, Purwo. 2017. The Influence of Firm's Size, Growth, and Profitability on Firm Value with Capital Structure as the Mediator: A Study on the Agricultural Firms Listed in the Indonesian Stock Exchange. International Journal of Economics and Finance 9: 103-10.

Harahap, Irwan Mangala, Ivana Septiani, and Endri Endri. 2020. Effect of financial performance on firms' value of cable companies in Indonesia. Accounting 6: 1103-10. [CrossRef]

He, Feng, and Rong Chen. 2007. Innovation, Firm Efficiency and Firm Value: Firm-Level Evidence in Japanese Electricity Machinery Industry. Paper presented at the 2007 International Conference on Wireless Communications, Networking and Mobile Computing, Shanghai, China, September 21-25; pp. 4217-20. [CrossRef]

Hirdinis, M. 2019. Capital structure and firm size on firm value moderated by profitability. International Journal of Economics and Business Administration 7: 174-91. [CrossRef]

Hirshleifer, David A., Po-Hsuan Hsu, and Dongmei Li. 2018. Innovative originality, profitability, and stock returns. The Review of Financial Studies 31: 2553-605. [CrossRef]

Hu, Yuanyuan, Shouming Chen, Yuexin Shao, and Su Gao. 2018. CSR and Firm Value: Evidence from China. Sustainability $10: 4597$. [CrossRef]

Huang, Peng, Yue Lu, and Marvin Wee. 2020. Corporate governance analysts and firm value: Australian evidence. Pacific-Basin Finance Journal 63: 101430. [CrossRef]

Jadiyappa, Nemiraja, Subramanian R. Iyer, and Pavana Jyothi. 2021. Does social responsibility improve firm value? Evidence from mandatory corporate social responsibility regulations in India. International Review of Finance 21: 653-60. [CrossRef]

Jo, Hoje, Hakkon Kim, and Kwangwoo Park. 2016. Environmental Costs and Firm Value. Asia-Pacific Journal of Financial Studies 45: 813-38. [CrossRef]

Kim, JooMan, Insun Yang, Taeyong Yang, and Peter Koveos. 2021. The impact of R\&D intensity, financial constraints, and dividend payout policy on firm value. Finance Research Letters 40: 10180. [CrossRef]

Kong, Dongmin, Lu Shi, and Zhiqing Yang. 2019. Product recalls, corporate social responsibility, and firm value: Evidence from the Chinese food industry. Food Policy 83: 60-69. [CrossRef]

Liow, Kim Hiang. 2010. Firm value, growth, profitability and capital structure of listed real estate companies: An international perspective. Journal of Property Research 27: 119-46. [CrossRef] 
Liu, Qingfeng, Hui Sono, and Wei Zhang. 2019. Management quality and acquisition performance: New evidence based on firm profitability. Journal of Corporate Accounting \& Finance 30: 44-63. [CrossRef]

McWilliams, Abagail, and Donald Siegel. 2000. Corporate social responsibility and financial performance: Correlation or misspecification? Strategic Management Journal 21: 603-9. [CrossRef]

Miguel, Edward, Shanker Satyanath, and Ernest Sergenti. 2004. Economic shocks and civil conflict: An instrumental variables approach. Journal of Political Economy 112: 725-53. [CrossRef]

Miller, Merton H., and Franco Modigliani. 1961. Dividend policy, growth, and the valuation of shares. The Journal of Business 34: 411-33. [CrossRef]

Miller, Merton H., and Kevin Rock. 1985. Dividend policy under asymmetric information. The Journal of Finance 40: 1031-51. [CrossRef]

Mousa, Musaab, Judit Sagi, and Zoltan Zeman. 2021. Brand and Firm Value: Evidence from Arab Emerging Markets. Economies 9: 5. [CrossRef]

Nagar, Venky, and Madhav V. Rajan. 2001. The revenue implications of financial and operational measures of product quality. The Accounting Review 76: 495-513. [CrossRef]

Olweny, Tobias. 2012. Dividend announcement and firm value: A test of semi strong form of efficiency at the Nairobi stock exchange. Asian Social Science 8: 161. [CrossRef]

Ong, Chorng-Shyong, and Po-Yen Chen. 2014. The effects of IT: From performance to value. Industrial Management E Data Systems 114: 70-85. [CrossRef]

Otero-González, Luis, Pablo Durán-Santomil, Ruben Lado-Sestayo, and Milagros Vivel-Búa. 2021. Active management, value investing and pension fund performance. European Journal of Management and Business Economics 30: 299-317. [CrossRef]

Salvi, Antonio, Filippo Vitolla, Michele Rubino, Anastasia Giakoumelou, and Nicola Raimo. 2021. Online information on digitalization processes and its impact on firm value. Journal of Business Research 124: 437-44. [CrossRef]

Sawicki, Julia. 2009. Corporate governance and dividend policy in Southeast Asia pre- and post-crisis. The European Journal of Finance 15: 211-30. [CrossRef]

Sharma, Neeru. 2003. The role of pure and quasi-moderators in services: An empirical investigation of ongoing customer-serviceprovider relationships. Journal of Retailing and Consumer Services 10: 253-62. [CrossRef]

Sharma, Neeru, and Paul G. Patterson. 1999. The impact of communication effectiveness and service quality on relationship commitment in consumer, professional services. Journal of Services Marketing 13: 151-70. [CrossRef]

Sinkin, Charlene, Charlotte J. Wrigh, and Royce D. Burnett. 2008. Eco-efficiency and firm value. Journal of Accounting and Public Policy 27: 167-76. [CrossRef]

Skinner, Douglas J., and Eugene Soltes. 2011. What do dividends tell us about earnings quality? Review of Accounting Studies 16: 1-28. [CrossRef]

Sohn, Byungcherl Charlie. 2016. The effect of accounting comparability on the accrual-based and real earnings management. Journal of Accounting and Public Policy 35: 513-39. [CrossRef]

Sutopo, Bambang, and Santoso Tri Hananto. 2019. Profitability and firm value: The impact of non-cash value flow recorded in the financial statements. International Journal of Economic Policy in Emerging Economies 12: 490-502. [CrossRef]

Thanatawee, Yordying. 2014. Institutional ownership and firm value in Thailand. Asian Journal of Business and Accounting 7: 1-22. Available online: http:/ / ssrn.com/abstract=2375648 (accessed on 4 July 2021).

Theodoulou, Giorgos, Nephytos Lembertides, and Andreas Charitou. 2010. The effect of past earnings and dividend patterns on the information content of dividends when earnings are reduced. Abacus 46: 153-87. [CrossRef]

Williams, Geoffrey. 2010. Socially Responsible Investment in Asia. Social Space. pp. 20-27. Available online: https://ink.library.smu. edu.sg/lien_research/62 (accessed on 4 July 2021).

Zaretzky, Kaylene, and J. Kenton Zumwalt. 2007. Relation between distress risk, book-to-market ratio and return premium. Managerial Finance 33: 788-97. [CrossRef]

Zhang, Jing, and Z. I. Shuang. 2021. Socially Responsible Investment and Firm Value: The Role of Institutions. Finance Research Letters 41: 101806. [CrossRef] 